\title{
LA REVUELTA DE LAS COMUNIDADES. UNA VISION DESDE LA SACRISTIA ${ }^{1}$
}

por

\section{EDWARD COOPER}

London Guildhall University

(En homenaje a Sir John H. Elliot)

RESUMAN: El onigen del liderazgo clerical de los comuneros en la dibcesis de Zamora se puede vincular con una combinación singular de circunstancias. La explotación de los recursos de la Iglesia por eclesiásticos y seglares ajenos creia continuamente divisiones cruciales. La custodía en Zamora de reliquias sin precio codiciadas por el arzobispado de Toledo ofrecta a Antonio Acuria, un obispo ambicioso de poca espiritualidad, material de sobomo para solicitar la primacia de España. Traicionado por la divergencia entre sus ambiciones y el programa de los rebeldes, el fracasado obispo, intemado en la cárcel real, se limitaba a esperar alguna intervención en su favor por los simpatizantes nobles que se habian implicado en la rebelion al principio. una figura crucial en lo que parece ser una conspiración para soltar a Acuña de las mazmorras de Simancas fue un racionero insignificante de la lejana catedral de Guadix, Lucas de Tauste. Entre junio de 1522 y febrero de 1525, ocupó lugares clave del sur de la diocesis de Zamora. De haber logrado Acuña salvar el recinto de Simancas y atravesar unos $75 \mathrm{kms}$. de despoblado del valle del Duero, el resto del recorrido, hasta la frontera de Portugal, le hubiera sido más o menos garantizado. Los datos sobre Tauste identifican como apoyo aristocrático, imprescindible para tal aventura, al marquess de los Veléz, el magnate del alumbre murciano. Indican además que la actuación zamorana de Tauste forma parte de una confrontación, a escala nacional, entre el marqués y el duque de Alba, sobre el control de los recursos del reino de Murcia.

Palabras clave. España, Castilla, Siglo XV1, Conflietos de Poder, Fistoria Social, Revoluclones, Fistoria Política.

1 Quiero agradecer la ayuda facilitada en la preparación de este trabajo a D. Jose Carlos de Lera Mafllo (archivero de la catedral de Zamora) a la Dra. Pauline Croft (Universidad de Londres), al Dr. Bartolomé Yun Casalilla (Universidad de Valladolid), a Dr̃a. Juana M. Huélamo Gabaldón, al Dr. Josep M. Solís Aris y al Subcomité de Investigación Científica y Desarrollo Profesional de la Facultad de Arte y Diseño de la London Guildhall University.

Hispania, LVI/2, núm. 193 (1996) 467.495 
ABSTRACT: The origin of clerical leadership of the comunero rebels in the diocese of Zamora can be linked with a unique combination of local circumstances. Manipulation of church assets by powerful ecclesiastical and lay interests elsewhere were crucially divisive, and the harbouring in Zamora of priceless relics coveted by the archbishopric of Toledo offered an ambitious but unspiritual bishop, Antonio Acuña, leverage to bid for the primacy of Spain. Betrayed by the discrepancy between his ambition and the aspirations of the rebels, the disgraced bishop, languishing in a royal prison, was reduced to the expectation of relief from some of the aristocratic connections implicated in the revolt in the first place. A crucial figure in an apparent plot to "spring" Acuña from the dungeons of Simancas, was an obscure prebendary of the remote diocese of Guadix, Lucas de Tauste. Between June 1522 and February 1525, he took over key points in the southem part of the diocese of Zamora. Had Acuña succeeded in breaking out and covering some 45 sparsely populated miles down the Douro valley, he would the have had a safe route to the Portuguese frontier. Tauste's connections suggest that the aristocratic backing indispensable for such a venture came from the Mucia alum magnate, the marquis of los Velez. and that the situation was part of a major confrontation between the marquis and the duke of Alba for control of the resources of the kingdom of Murcia.

KeY words: Spain, Castilla, XVI century, Social History, Revolutions, Political Fistory.

Los objetivos del movimiento comunero de Castilla permanecen abiertos al debate, aunque queda fuera de toda duda el detonante que lo precipito: la aprobación de un servicio extraordinario por parte de los procuradores castellanos para sufragar los gastos de la eleccion imperial en 1520. La hostilidad crecí, si es que no se inició entonces, cuando los procuradores de vuelta a sus ciudades informaron de su actuación. Entretanto la Corona pudo identificar a la mayoría de los participantes. Sin embargo, después de unas primeras ejecuciones ejemplarizantes y de perdonar a aquellos que habian sido manipulados, fue incapaz de imponer fuertes castigos a los verdaderos culpables y sólo pudo especular con la posible complicidad de otros, fundamentalmente miembros de la nobleza.

Aunque el subsidio resultaba oneroso para las ciudades representadas en las Cortes de La Coruña no afectó a los líderes eclesiásticos y aristocráticos comuneros. No sólo no les afect6, sino que comprendieron la urgencia de las peticiones de Carlos. La reina legitima era su madre, la viuda Juana la Loca. Carlos paso en 1516 a actuar como regente del mismo modo que lo hiciera con anterioridad Fernando el Católico dada la incapacidad de Juana. Ante las naciones europeas esta situación privaba a Carlos de posibilidades de negociar por lo que le fue necesario conseguir una posición más fuerte y ésta se la brindó la Corona Imperial.

La historiografía ha centrado su atención en Antonio de Acuña (1459. 1526) Obispo de Zamora, máximo dirigente de los rebeldes ${ }^{2}$. Sin embargo, si

\footnotetext{
2 Gularte Zapatero, A. M., El Obispo Acuña, Valladolid 1979.
} 
un Obispo encabezaba a los rebeldes, ¿por qué razón no tomaron parte el resto de los prelados?. Aunque el obispado de Zamora era de categoría media, durante los meses de la crisis alcanzó una importancia primordial. La imprecisión respecto al parentesco de Acuña, la cronología de sus actividades y el propio significado de su cargo episcopal impiden establecer las motivaciones que le llevaron a dirigir el movimiento comunero. Estas carencias me han llevado a dar prioridad a las peculiaridades del contexto diocesano, a la identificación de personajes claves y al establecimiento de un orden riguroso de los acontecimientos que se desarrollaron en Zamora y que tuvieron una transcendencia más allá de la puramente local. De esta forma quedará claro porqué esta diócesis ofreció un terreno tan fértil para la rebelión.

En primer lugar se produjo una polémica fiscal que animaría a un sector del clero a involucrarse en las Comunidades. En segundo lugar, Zamora ofrecía una oportunidad única para impulsar una carrera personal que hasta entonces había sido mediocre. La naturaleza de la diócesis implicaba una multiplicidad de intereses ajenos. Los apoyos de Acuña provenían de una red de contactos eclesiásticos a los que se unía una serie de enlaces familiares y, en los últimos momentos, un personaje de gran importancia política.

La delimitación de la diócesis de Zamora en aquel momento dista mucho de la actual. El obispado debía su independencia de Braga y Toledo a la intervención de los arzobispos de Santiago. A principios del siglo xvI no estaban tan mediatizados aunque los arzobispos continuaban interviniendo debido a que un enclave importante, la vicaría de Alba y Aliste, continuaba formando parte de la diócesis de Santiago ${ }^{3}$. Debido a una antigua anomalía histórica Zamora representaba a Galicia en las Cortes. Por lo tanto en las de Santiago/La Coruña de 1519/20 los arzobispos tenían motivos para entrometerse en los asuntos de Zamora. Otro enclave fue la vicaría de San Millán en el valle del Esla, sujeto a la mitra de Oviedo ${ }^{4}$. También independientes fueron las encomiendas de las Ordenes de San Juan, en el cauce del Guareña ${ }^{5}$, y de Santiago (Peñausende, Castrotorafe y Villalba de Lampreana ${ }^{6}$ ).

La mayoría de las administraciones bajomedievales tuvieron que soportar enclaves jurisdiccionales, aunque el caso de Zamora puede considerarse extremo: los mayorazgos de los tres nobles zamoranos más importantes, los Condes de Benavente y de Alba de Liste y el primo de su padre Francisco Enriquez de Almanza, estaban situados dentro de estos enclaves episcopales. La fragilidad de la infraestructura eclesiástica quedó aún más al descubierto por una disputa que estallo en crisis en 1507. Este hecho coincidió con el enfrentamiento entre Acuña (instalado por aquel entonces en la sede

\footnotetext{
${ }^{3}$ Aparte de las parroquias situadas al oeste del valle del Esla, entraban las urbanas de Santiago del Burgo y Arquellinos incorporadas a la diócesis de Zamora tardíamente en 1888.

4 Con Benavente.

5 La dependencia de Acuña de la colindante Fuentesaúco durante los primeros momentos de su ocupación de la diócesis fue motivo de repetidas escaramuzas (COOPER, E., Castillos Señoriales en la Corona de Castilla, Valladolid, 1991, ap. doc. núm. 359).

6 Incorporados en 1875.
} 
episcopal por la fuerza de las armas) y el Rey Católico de vuelta en Castilla para ejercer la regencia.

Durante los tres años anteriores un regidor de Tordesillas, el capitán Francisco Vázquez de Cepeda, había estado reclamando ante la Corona las tercias de los diezmos de Casasola de Arion y otras parroquias del arcedianato de Toro. La Corona perdí6 sus derechos cuando Alvaro Gómez de Jaen, prior de Salamanca y cura de Santa María de Casasola apoyado por otros litigantes se hizo con los frutos en cuestión ${ }^{7}$. Luego, Alvaro Gómez, el único que era sacerdote, los permutó con el Dr. Cepeda, residente en Roma y pariente con toda probabilidad de Francisco Vázquez. A su vez Cepeda intentó cambiar el curso de la justicia transfiriendo el proceso al Vaticano.

De los cinco contendientes por las tercias de Casasola, los verdaderos protagonistas resultaron ser Francisco Vázquez y Juan de Ulloa, Señor de la Mota, quien en un principio respald6 a Alvaro G6mez. No se conoce la resolución final. No obstante existía el peligro de una pérdida de recursos eclesiásticos y de que este tipo de disputas se volviera a repetir ya que el pleito de Casasola afectaba a un total de nueve parroquias y otros dos seglares reclamaban las tercias de distintas localidades de la diocesis. Uno de ellos, Juan de Vega basó sus derechos en el mismo privilegio que Francisco Vázquez. En vísperas de la rebelión el consejero real Hernando, primogénito de Juan de Vega, reconstruyó su castillo de Grajal de Campos ${ }^{B}$. No se trata de una mera coincidencia de fechas ya que Alvaro Gómez, claro aliado de Acuña, se distanció pronto de Ulloa para destacarse después en las filas comuneras animado sin duda por su exclusión del pleito de las tercias de Casasola. Gómez y Acuña tendrían además especial interés en oponerse a la salida de riquezas de la diócesis.

A su vez el ejemplo de Casasola pudo servir de precedente, en noviembre de 1520, en el intento del Conde de Benavente, el Marqués de Astorga y el Obispo de Astorga ${ }^{9}$ de efectuar un reparto de los ingresos del obispado de Zamora. Sin embargo, quien ejercía el verdadero control del Regimiento de Zamora en este momento era Diego Enríquez de Guzmán, Conde de Alba de Liste. Al contrario que el Conde de Benavente, que simplemente tenía regidores asalariados, el Conde de Alba presidía con regularidad las reuniones de los ediles y se interesaba por el bienestar del municipio. Aunque Alvaro Pérez Osorio ${ }^{10}$, tío de Acuña, le había destitúdo sumariamente de la alcaidía de Zamora en 1506 no existen indicios de hostilidad entre el Obispo y el Conde

7 Archivo de la Real Chancillería, Valladolid: M. Pérez Alonso. Pleitos Civilies Fenecidos C 46I, C 626-I y C 627-I. Es probable que precipitara la disputa un aumento de población en las parroquias afectadas, mejorando proporcionalmente su rentabilidad.

8 COOPER, págs. 385-6 y fig. 393

9 Álvarez Osono, GullarTe, pág. 178. No fue una novedad, el 3 de diciembre de 1519 el Regimiento nombró procurador a Diego Rodríguez Salazar, con el encargo de lograr que el Emperador garantizara el libre tránsito de viveres de la ciudad por el obispado de Astorga (Archivo Histórico Provincial de Zamora XX-poderes).

10 GuilaRTE, pág. 56.

Hispania, LVI/2, nuim. 193 (1996) 467-495 
de Alba. En los primeros momentos de la rebelión el Conde mantuvo el diálogo entre el Regimiento y la Junta de Avila evitando al mismo tiempo comprometerse con los rebeldes.

Al igual que Juan de Ulloa cuyos dos hermanos y un primo fueron comuneros, el hermano de Acuña, Diego Osorio, regidor de Burgos permanecí incondicional a la Corona durante los acontecimientos de 1520-1 y las secuelas posteriores. También Acuña había servido fielmente al Estado hasta 1507 momento en que accede al obispado ". En esta ocasión parece que la Corona aceptó los hechos consumados y por su parte Acuña actú después como embajador real. En todo ello se puede apreciar claramente su sesgo oportunista: identificó la puerta que le era accesible desde la fragmentada diócesis, consiguió la llave y aguardó el momento para utilizarla. La llave no era otra que la devolución de los restos de San Ildefonso, patrón de la catedral de Toledo, conservados en la iglesia zamorana de san Pedro fuera del alcance musulmán hasta fines del siglo $\mathrm{xv}$, cuestión que había llegado a ser obsesiva para los fieles de la ciudad imperial.

El empeño de las autoridades zamoranas en salvaguardar su más precioso tesoro se convirtió en desafío en 1496 con la construcción de una suntuosa capilla en la iglesia de san Pedro para exponer las veneradas reliquias. Custodiarlas fue responsabilidad de la cofradía de san Ildefonso, cuyos miembros incluían no sólo a personas de importancia local como el deán Diego Vázquez de Cepeda (probablemente pariente del capitán Francisco Vázquez), sino también a personalidades de toda Castilla incluyendo al propio Antonio de Acuña, al Duque de Alba y posteriormente incluso a Carlos V. En el otoño de 1505 el cardenal Cisneros intentó hacerse con las reliquias presumiblemente para llevarlas a Toledo ${ }^{12}$. Desde entonces, mientras el astuto franciscano se mantuvo como Arzobispo, la prioridad de Acuña como Obispo de Zamora fue impedir que se repitiera el ardid hasta que él mismo tuviera ocasión de explotar todo el potencial de las reliquias. A medida que el anciano Cisneros se debilitaba lo mismo ocurría con el interés de Acuña por la cofradía de san Ildefonso hasta el punto de que se opuso al jubileo del 17 de junio de 1517 para recaudar fondos para la iglesia de san Pedro. Luego fue evidente su intento de prohibir que se expusiera al pueblo el cuerpo del santo. No obstante la negativa, el acto se llevó a cabo el 28 de septiembre ${ }^{13}$.

Finalmente las oscuras intenciones de Acuña respecto a las reliquias de san Ildefonso dependieron de la manipulación de posibles aliados e intereses contrapuestos en el poco prometedor contexto de una desvencijada diocesis. Había iniciado su carrera como arcediano de Valpuesta en la diócesis de Burgos. Su lle-

\footnotetext{
11 COOPER, ap. doc. núm. 313.

12 Fernández Prieto, E, Nobleza de Zamora, Madrid, 1953, pág. 421. Cabe suponer que Cisneros quería las reliquias para su colegio de San Ildefonso de Alcalá de Henares, cuya inauguración en 1508 estaba probablemente preparando.

13 Presenció bajo protesta, Gonzalo Monte (Idem: Actas de Visitas Reales y otras realizadas por acontecimientos extraordinarios a los cuerpos santos de san Ildefonso y san Atilano, Zamora, 1973,
} pág. 37). 
gada a Zamora en 1507 fue probablemente favorecida por Alvar Pérez de Osorio. Acuña no vaciló en cubrir los cargos vacantes en Zamora con clérigos burgaleses, en particular su provisor y hombre incondicional durante la época comunera y finalmente albacea, el Dr. Gonzalo Monte y su secretario Fernando Hontañón de Medinilla ${ }^{14}$. En algún momento se avino a ceder el arcedianato al deán de Burgos Pedro Suárez de Velasco, hijo bastardo del Condestable de Castilla, y tal acuerdo pudo haberle garantizado el apoyo de este último en su aventura zamorana. Sin embargo una vez instalado en su diócesis se negó a renunciar a Valpuesta. A finales de 1517 el deán de Burgos solicitó la suspension del episcopado de Acuña ${ }^{15}$. No hay duda de que las rentas de Valpuesta eran sustanciosas. Además, para Acunia, abandonar el arcedianato hubiera podido perjudicar también los intereses de los clérigos burgaleses ${ }^{16}$ que habia introducido en la dibcesis perdiendo entonces su apoyo.

Es probable que, de los enclaves jurisdiccionales de la diócesis de Zamora, el correspondiente a la Mitra de Oviedo apoyara a Acuña al menos durante el mandato de Diego de Muros (1512-25). Esta diocesis septentrional estaba también sujeta a que Toledo reclamase la devolución de las reliquias ${ }^{17}$, y en particular la casulla de san Ildefonso. Otra circunstancia que favorecia la solidaridad ovetense con Zamora radicaba en la posesión por parte de racioneros zamoranos de beneficios clave de la dibcesis asturiana: por ejemplo, el canónigo zamorano Juan Vázquez de Mella ${ }^{18}$ fue arcediano de Tineo. La sustitución del canónigo Alonso de Valdivieso (apellido burgalés, fallecido el 26 de febrero de 1518) está en la misma línea. Sorprendentemente Antonio de Acuña asistió al nombramiento de su sucesor en el cabildo el 1 de marzo ${ }^{19}$. En este caso se trataba de Alonso de Gijón cuyo apellido parece de origen ovetense aunque fuera clérigo zamorano. La presencia del Obispo evidencia el interés en que Gijón fuera aceptado. Quiź́ Acuña esperaba sustituir a todos sus seguidores burgaleses por clérigos ovetenses. Sin embargo, Gijon tuvo la oportunidad de hacerse valer antes de que la situación hubiera llegado a este punto.

El deán de Zamora en el momento de la elección de Gijón era todavía Diego Vázquez de Cepeda. Figuraba de nuevo como deán el 8 de agosto ${ }^{20}$. En

14 Elegido a una canonjía el 29 de abril de 1513, Archivo de la Catedral de Zamora 42.

is GuILARTE, pág. 71.

16 Por ejemplo el canónigo Damián Zorrilla, elegido el 20 de septiembre de 1507 (Archivo de la Catedral de Zamora 42).

17 También los huesos de santa Leocadia y san Julián. SALAZAR DE Mendoza, Pedro, El Glorioso Doctor San Ildefonso, Toledo, 1618, págs. 189-90.

18 Los Mella tenían probablemente mayor peso que ningún otro linaje clerical de Zamora. Al final de la Edad Media, la escasa grandeza que le quedaba a la Mitra se debía al Cardenal Juan de Mella (1397-1467), Obispo de Zamora, y a su hermano Fernando de Mella, Obispo de Lydda, administrador de la diócesis en ausencia de aquél. El arcediano de Tíneo en ese momento era el Dr. Luis Vázquez de Mella.

19 Archivo de la Catedral de Zamora 42.

20 En tal ocasión permutó su beneficio de san Pelayo de Casasola de Valderaduey por el de san Esteban de Zamora (ibidem, 18, núm. 30).

Hispania, LVI/2, ním. 193 (1996) 467-495 
el cabildo del 1 de noviembre consta como ausente sustituyéndole el subdeán Luis Temiño ${ }^{21}$. El siguiente capítulo cuyas actas se conservan es del 6 de agosto de $1519^{22}$. No hay entonces mención de Diego Vázquez ni siquiera como canónigo. El deán es ahora un tal Pedro Pérez que carece de antecedentes documentales y mucho menos como canonigo ${ }^{23}$. Quienquiera que fuera parece haber sido nombrado por encima del subdeán que había sido relegado a una simple canonjía. En ausencia de Pérez, Gonzalo Monte desempeñaba sus funciones, incluso tomaba la iniciativa cuando el primero estaba presente, enmarañando aún más la ilegalidad de los procedimientos.

No hay constancia de que se intentasen legalizar estos cambios. Sin embargo, con Toledo vacante tras la muerte de Cisneros en 1517, posiblemente Diego Vázquez pudo temer la aparición de nuevas conspiraciones para secuestrar las reliquias de san Ildefonso. Respecto a Toledo, Carlos V propuso dividir la diócesis en tres para facilitar el establecimiento de Guillermo de Croy (ausente y menor de edad) como Primado. Fue difícil sofocar las protestas aún después de la anulación papal de la división de la diócesis el 23 de julio de 1518. La verdad era que los canónigos toledanos no querian a Croy ni deseaban la fragmentación de la diócesis pero estaban dispuestos a aceptar a éste con tal de evitar la división.

La frágil situación de Croy deparó a Acuña una oportunidad de oro. No obstante parece que el Obispo no intentó aprovecharla. Habrían influído en esta decisión la actitud imprevisible de los canónigos toledanos, la intervención del Marqués de Villena, pariente de Acuña, para que el cabildo metropolitano aceptara las peticiones de Carlos V y la exclusividad de los tres obispados sufragáneos propuestos ${ }^{24}$. Sin embargo, el deán de Zamora lleg6 a elaborar el 12 de junio de 1518 unos estatutos para la provisión de hachones para acompañar el cuerpo del Señor en el Corpus Christi, con una dotación

${ }^{21}$ Nombramiento de Pedro de Luarca (apellido asturiano, aunque aparece como clérigo de la diócesis de Zamora, ibidem, 144, caja I).

22 Ibidem, 42.

23 He tomado por supuesto que no se trata del notario de la Audiencia Episcopal de Zamora, de idéntico nombre, pues éste actuaba en pro de Pedro de Bey, mientras que el deán era claramente partidario del Obispo. Además, un sólo individuo no sería capaz de desempeñar dos oficios tan incompatibles el mismo día.

24 Las razones de la postura del Marqués de desconocen (su padre era primo del abuelo de Acuña). Las propuestas para la diócesis consistieron en que hasta 1524 Croy ocuparía el obispado de Toledo; uno de los sufragáneos sería Bernardino Carvajal y el otro o Diego de Toledo o Antonio Zúñiga (aspirante él mismo al arzobispado). Esta solución se vio perjudicada por la complicación con problemas ajenos: el propósito fue sobornar a Carvajal para que abandonara su enfrentamiento con Fadrique de Portugal en lo referente al obispado de Sigüienza y compensar al perdedor de la disputa entre Zúñiga y Don Diego por el Priorato de san Juan. Acuña respaldaba a Diego como Prior. Fuera el que fuera el resultado la tripartición del obispado de Toledo le habría quitado todas las ventajas. Poschmann, A., El Cardenal Guillermo de Croy y el arzobispado de Toledo, Boletín de la Real Academia de la Historia, vol. LXXV 1919, págs. 220-5. 
de 100.000 mrvds. para apoyar su cumplimiento ${ }^{25}$. Presumiblemente los canónigos zamoranos no tuvieron nada en contra de los emolumentos recibidos por portar los hachones lo que a su vez aumentaría la fidelidad al deán en su ausencia. Aunque parece que Acuña no se opuso a su ída, Diego Vázquez se cuid6 mucho de desvelar su destino. Como protonotario apostólico no pudo ser otro que Roma, seguramente via Toledo. Su decisión de marcharse pudo verse acelerada por otro intento de llevarse a san Ildefonso por parte de un sacerdote toledano disfrazado. El ardid fracasó cuando el delincuente decapitó por error a otro santo, trasladándose a Toledo en lugar de la cabeza de san Ildefonso la del menos venerado san Atilano ${ }^{26}$.

El anteriormente mencionado cabildo de 6 de agosto de 1519 se convoco para cubrir el puesto de Juan de Mella, fallecido el día anterior. Los canónigos acordaron conceder la canonjía a Alonso Bonilla y el beneficio de Santa Maria de Inhiesta a Antonio Barrientos. Ambos eran clérigos de la diócesis de Zamora. Normalmente en esa época no se tardaba mucho en cubrir las canonjias vacantes. No obstante, la rapidez del caso, la irregular recomposicion del cabildo y el hecho de que Barrientos fuera menor de edad indica que los can6nigos se enfrentaban a una crisis ocasionada por los intentos de los enemigos de Acuña de ocupar el vacío producido por la ausencia de Diego Vázquez de Cepeda. Probablemente los canónigos conocían una bula de León X de 1 de noviembre de 1517 esgrimida por un clérigo de Santiago de Compostela, Pedro de Bey, en la que se le admitfa en las canonjías de Zamora y Palencia además de en su propia diócesis. Acto seguido llegó un breve del mismo pontífice de 25 de febrero de 1518 , otorgando una canonjía (la vacante siguiente), además de otra en Palencia con un arcedianato a Juan Beltrán, un clérigo residente en Roma. Antón Gómez, representante de Beltrán se encastilló en Santa María de Inhiesta aunque parece que el beneficio era independiente de la canonjia.

Beltrán fue un aspirante habitual a beneficios zamoranos durante la tercera década del siglo xv. Reclamó también el beneficio de Cerecinos de la Carrizal, ostentado por el canónigo Pedro de Mazariegos, protonotario apostólico. El 18 de octubre de 1518 se personó en Zamora el Obispo de Badajoz Pedro Ruiz de la Mota para autorizar a Juan Becerra y a Francisco Ledesma, vecinos de Zamora, a ocupar cualquier beneficio vacante que pudiera corres-

25 Archivo de la Catedral de Zamora 18, núm. 30. Cepeda parece permitirse una ausencia de seis años (el plazo de la propuesta de división de la diócesis de Toledo). Aunque en el calendario eclesiástico el Corpus Christi va a continuación de la fiesta del Descubrimiento y Traslado del Cuerpo de san Ildefonso ( 26 de mayo), no existe una relación obvia entre la cofradía y la fundación del deán. La gestión coincidió posiblemente con una epidemia de peste, pudiendo influir ésto en la aprobación del pueblo, pues los hachones servían para acompañar el cuerpo del Señor por las casas de los aquejados.

26 LOBERA, Athanasio, ... La Historia de la Vida y Milagros del Glorioso San Atilano..., Valladolid, 1596, págs. 412-3. Se desconoce la fecha de este incidente, y el muy parcial Salazar de Mendoza (pág. 219) niega que la cabeza de Atilano llegase a Toledo. Sin ernbargo no dispone de pruebas de que el propio error fuera una ficción.

Hispania, LV/2, num. 193 (1996) 467-495 
ponder a Beltrán. El cabildo del 6 de agosto de 1519 recibio también una demanda de Becerra respecto a la canonjía de Juan de Mella ${ }^{27}$. Agobiados por este bombardeo, el deán y el cabildo nombraron a Juan de Angulo (secretario del Conde de Alba de Liste), procurador de Bonilla y Barrientos ante el juez ejecutor del caso, Juan Pérez, comendador de La Merced de Valladolid. Al final se salieron con la suya Bonilla y Barrientos como parece que fue la intención de Acuña, entonces ausente ${ }^{28}$.

$\mathrm{El}$ andariego prelado volvió a Zamora en septiembre de 1520 tras dos años y medio fuera. Se le negó el acceso a la ciudad y tuvo que alojarse en Toro. En los trece meses anteriores se había retirado de la vida pública de la misma forma que Diego Vázquez de Cepeda, desconociéndose su itinerario en este periodo ${ }^{29}$. Sin embargo, lo más probable es que si Roma fue el destino del deán de Zamora, el Obispo le siguiera para intentar neutralizar sus esfuerzos. La inicial cautela del Emperador sobre el Primado de Croy parece haber desembocado en dudas, alimentando con ello las pretensiones de Acuña ${ }^{30}$. Este, sin embargo, una vez de vuelta, se mantuvo al margen de la rebelión comunera hasta el 9 de septiembre. En esta funesta fecha la situación cambio radicalmente cuando el corregidor de Zamora, respondiendo a una demanda del cabecilla Juan Padilla, expulsó al Conde de Alba de Liste saliendo después él mismo de la ciudad ${ }^{31}$.

Tres días más tarde entró Acuña en Zamora y asistió al siguiente nombramiento polémico tratado por el cabildo: la elección, el 23 de septiembre, de un

27 Fadrique de Portugal, Obispo de Sigüenza había abogado por Ruiz de la Mota. ¿Podría ser consecuencia de alguna interferencia de Acuña en la lucha de éste con Carvajal?. Como ocurrió con otra documentación de la época comunera de los archivos zamoranos, los de la ciudad además de los episcopales, la copia de tres páginas del expediente de Portugal ha sido extraviada, quedando tan sólo las huellas de las tijeras en los folios del legajo. El culpable, en este caso, pudo ser el mismo Portugal preparando un dossier en su defensa en 1526, véase nota 106.

${ }_{28}$ El 9 de agosto de 1520 Bonilla renunció a su canonjía en favor de Barrientos, quien a su vez había obtenido una adjudicación de León X que excluyó a Beltrán y a un tal Cristóbal Méndez (Archivo de la Catedral de Zamora 144, caja I). Cabe suponer que con esto Acuña pensaba añadir al cabildo un voto totalmente complaciente. Sin embargo parece que Barrientos nunca fue explotado de esta manera.

29 Un relato sin base documental adjudica a Acuĩa y a la Condesa de Alba de Liste la protección de los procuradores de Zamora en las Cortes de La Coruña de 1520, contra la ira del populacho, cuando se aventuraron en mayo del mismo año a volver a la ciudad que representaban. Ed. Lópz de TORo, J., Epistolario, de Pedro Mártir de Angleria, 4 tomos, Madrid, 1953, ed. Duque de Alba et al, Documentos Inéditos para la Historia de España, vols. 9-12, carta 670. Sin embargo es probable que el autor no supiera si el Obispo estaba personalmente presente o no.

30 El 5 de junio de 1520 el Cardenal Wolsey fue naturalizado para desempeñar cargos eclesiásticos en los reinos de Castilla, León y Granada. La única dignidad que le habria interesado hubiera sido la silla de Toledo. Un mes más tarde se nombró Obispo de Badajoz a Christopher Bainbridge, Arzobispo de York como sucesor de Pedro Ruiz de la Mota, pero renunció enseguida. Con ésto terminó la intrusión inglesa, aunque la Santa Junta solicitó la salida de Croy el 20 de octubre (CoOPER, pág. 147). Es inverosímil que vieran en Acur̃a un sustituto.

${ }_{31}$ Fernández Alyarez, M., Zamora en Tiempos de Carlos V, Primer Congreso de Historia de Zamora, vol. 3, Zamora, 1991, págs. 433-458, pág. 444. 
sucesor en la canonjía doctoral del difunto Obispo de Mondoñedo, el Dr. Diego Pérez de Villamoriel ${ }^{32}$. Se empató la elección celebrada el 4 de octubre con diez votos para cada candidato: Pedro González Manso, deán de Granada y miembro del Consejo de la Inquisición y el licenciado salmantino Gaspar de Montoya ${ }^{33}$. Cabe suponer que los canónigos partidarios de éste tenían beneficios en la vicaría de Alba y Aliste, pues Montoya representaba efectivamente los intereses del Arzobispo de Santiago. Manso, por otra parte, fue también abad de santa Marta de Ribadetera, próxima a la vicaría ovetense de san Millán ${ }^{34}$. Fue favorecido por Acuña y el apoyo del Obispo dependía probablemente de que éste le consiguiera las rentas de la abadía, retenidas según parece, por un criado del Duque de Alba ${ }^{35}$. Sin embargo, no prevaleció la opinión de Acuña y la canonjía doctoral permanecía aún desierta en 1524.

A continuación volvió Acuña a Toro. En diciembre de 1520 trasladó su centro de operaciones a la colindante diócesis de Palencia donde se dedicó a arrasar las fortalezas del Obispo y del Conde de Buendía. Es a partir de este momento cuando se le puede denominar jefe del movimiento comunero: si se hubiese encargado Padilla de la campaña entonces, es probable que hubieran quedado en pie las fortificaciones de Dueñas, dominio del Conde de Buendía, ya que la Condesa era prima de la mujer de Padilla, y el hermano de éste estaba casado con la sobrina de aquella ${ }^{36}$. La localización palentina del patrimonio de tres de los interesados en las tercias de Casasola, más la amenaza a la unidad del cabildo zamorano en este tiempo hacen lógico el asalto de Acuña al Obispado de Palencia. Fue en esa diócesis, concretamente en Valladolid, donde se adjudicó la canonjía de Juan de Mella. El Obispo en tiempos

${ }^{32}$ Archivo de la Catedral de Zamora 190 núm. 1. Diego Pérez de Villamoriel había adjudicado inicialmente en el pleito de las tercias de Casasola. FERnANDez AlvareZ, La Zamora Comunera en 1520, Studia Hístórica (Historia Moderna) 1983, vol. I, núm. 3, págs. 7-27, pág. 20 se equivoca al aseverar que durante estos sucesos Acuña fue excluído de la ciudad.

33 El tesorero Antonio Ocampo intentó votar dos veces por Montoya, primero como canónigo, y después en su calidad de tesorero. Fue rechazado por Gonzalo Monte, el único que registró dos votos sin oposición. De hecho varios canónigos gozaban teóricamente de un segundo voto ex officio, pero ningún otro lo utilizó. Pedro López, procurador de Manso, insistió en que los deseos del Obispo sobre este punto tuvieran carácter resolutorio.

${ }^{34} \mathrm{Y}$ amigo también de Pedro Mártir desde hacía muchos años. Pasaron juntos la época de crisis de la rebelión de agosto de 1520 a mayo de 1521 en Valladolid, ed. LOPEZ DE TORO, cartas 8, 698, 721 , etc. A pesar de la localización granadina de su dignidad, Manso era otro clérigo burgalés. SuÁREZ, P., Historia del Obispado de Guadix y Baza, Madrid, 1696, págs. 182-4. Paradójicamente Mártir era poco favorable a Acuña.

${ }_{35}$ Enrique Páez de Sotomayor, de Alcalá de Henares. Como corregidor de Ponferrada había sido administrador de la abadía cuando estaba en tercerias, negándose después a entregar a Manso el saldo de su estipendio. Una solicitud sin fecha dirigida al Emperador para que obligara a aquél a cumplir no hace referencia al deanato de Granada o al Consejo de la Inquisición, al cual pertenecia Manso, dando a entender que la situación fue anterior a 1520 (Archivo General de Castilla, Simancas, AGS, Cámara de Castilla 137-303).

${ }_{36}$ COOPER, ap. doc. 159. Quien mandaba realmente en el condado de Buendía era probablemente la Condesa, pues parece que el Conde se volvió loco y moría en 1521.

Hispania, LVI/2, núm, 193 (1996) 467-495 
del proceso era Juan Rodríguez Fonseca, primo del padre del Arzobispo de Santiago, y cuyo hijo bastardo Iñigo era otro aspirante al arzobispado de Toledo. Este Obispo además había patrocinado a un candidato rival para la canonjia que ganó en 1513 Fernando Hontañon de Medinilla ${ }^{37}$. Repentinamente, Fonseca se convirtió en Obispo de Burgos y el 4 de julio de 1520 el Obispo de Badajoz fue nombrado Obispo de Palencia.

El 6 de enero de 1521 murí en Flandes a los 23 años de edad Guillermo de Croy, Arzobispo de Toledo. La Santa Junta autorizo a Acuña a requisar los ingresos de la archidiócesis para aliviar las agotadas finanzas de los rebeldes. Fue animado por Pedro González Manso ${ }^{38}$. Pero el apoyo de éste no quiere decir que Acuña siguiera las normas jurídicas respecto a la investidura de prelados, a pesar de la similitud con las circunstancias que rodearon su ocupación de la silla de Zamora en 1507. De otra manera contemporáneos como Mártir o Antonio Guevara lo hubieran señalado.

De hecho Acuña interpretó su mandato de forma interesada y a pesar de la desesperada situación económica, tardó más de un mes en llegar a Toledo desde Palencia, debido en gran parte a una dilatada estancia en Alcalá de Henares. La ciudad universitaria ya habŕa abrazado la causa comunera de modo que muy bien pudo dedicar el tiempo a discutir cuestiones de derecho canónico. Pero como la Universidad consistía realmente en el Colegio de san Ildefonso, fundado por Cisneros, existe otra posibilidad: Acuña puede haber estando pensando en intentar permutar las reliquias de san Ildefonso por la Mitra de Toledo. Para que aceptaran tal propuesta los canónigos de Toledo, cuya posición en ese momento era una incógnita, sería importante contar con el apoyo del indeciso rector del Colegio, Juan de Hontanón ${ }^{39}$. Fuera el que fuera el motivo del retraso, las consecuencias f́ban a ser absolutamente negativas.

Acuña llegó por fin el 29 de marzo e intentó destituir a Francisco Mendoza Quiñones, administrador de la diócesis y tío de María Pacheco, mujer de Juan Padilla. La ejecución del cabecilla, tras la derrota comunera de Villalar el 23 de abril proporcionó gran relevancia a su viuda cuyo propósito fue lograr para su hermano Francisco Mendoza Pacheco la silla de Toledo. Esto chocaba frontalmente con las intenciones de Acuña pues le amenazó con reducirle a cero. Para los rebeldes, todavía desorientados después del fracaso de Villalar, la propuesta de María Pacheco era mejor que las ambiciones de Acuña, ya que prometió atraer a la causa comunera al importante clan de los Mendoza, en

37 El capeltán real Tomás García, clérigo de la diócesis de Tarazona (Archivo de la Catedral de Zamora 144, caja I).

38 PÉREZ J., La Revolución de las «Comunidades» de Castilla, 1520-1521, versión española, Madrid, 1977 pág. 320. Manso tenía una cátedra en la Universidad de Valladolid y pudo aspirar también a otra en Alcalá.

39 Acuña le «ofreció», por ejemplo, la sede vacante de Jaén (ibidem, pág. 331), buscada también por Pedro Ribera, Obispo de Lugo (AGS Patronato Real 3-19). El hermano del difunto cardenal, fray Bernardino, profesor del colegio de Alcalá fue un conocido cornunero, cosa lógica dados los esfuerzos de Cisneros para adquirir los restos de san Ildefonso. 
lugar de hostigarles. Aunque ella no tenía la ventaja absoluta, la división fue desastrosa para Acuña. Los canónigos toledanos evitaban comprometerse. La defensa rebelde de Toledo vacilaba. El día 28 del mismo mes la Corona nombr6 al Conde de Alba de Liste receptor de los bienes del obispado de Zamora ${ }^{40}$. Aunque Acuña consiguió huir de la Ciudad Imperial hacia mayo de 1521, fue detenido en los dominios del Duque de Nájera cerca de la frontera de Navarra y su carrera se desmoronó en ese momento.

Humillado, se rebajo a pedir al marqués de Villena que hiciese llegar al duque de Alba una temblorosa solicitud de auxilio ${ }^{41}$. El Duque era probablemente la única esperanza para Acuña de reanudar sus relaciones con la cofradía de san Ildefonso, de lo cual dependían sus posibilidades de mantenerse en su diocesis. Además, Diego de Toledo, el candidato favorecido por Acuña para el disputado priorato de san Juan, era hijo del Duque. El 2 de septiembre Acuña avisó al Obispo de Oviedo, Diego de Muros, que fba a entregar la fortaleza episcopal de Fermoselle (uno de los pocos inmuebles de la Mitra que quedaban en su poder) al Duque de Nájera (Muros ya había asumido la receptoría del Obispado de Zamora) ${ }^{42}$.

Ambas gestiones fueron ineficaces: en el verano de 1522 Acuña comenzó su encarcelamiento de tres años y medio en Simancas situada, irónicamente a unos $30 \mathrm{kms}$. al este del funesto campo de Villalar (localizado a su vez a tiro de piedra de Casasola), el extremo oriental de su diócesis. En septiembre, una visita del cortesano Enrique de Nassau, que se comprometió a ofrecer al Emperador un rescate de 40.000 ducados ${ }^{43}$ a cambio de su libertad, aliment 6 la ilusión de una salida bajo palabra. Quienes podrían reunir esta pequeña fortuna, según algunos, serían el Duque de Nájera, el Condestable de Castilla y un Obispo portugués, cuffado de Alvar Pérez Osorio ${ }^{44}$. La Corona no respondio: de haber existido realmente dicha suma, se habría agotado sólo con satisfacer las demandas de los acreedores de Acuna (como ocurrio con otros comuneros) una vez que sus recursos fueron retenidos. Incluso parecía imposible que se produjera una suspensión de la sentencia: el embajador del

\footnotetext{
40 Gullarte, pág. 179.

41 Bidem, pág. 224. El Duque de Alba de Tormes era primo del padre del Conde de Alba de Liste.

42 Ibidem, págs. 225-6.

43 Ibidem, pág. 176.

44 Ibidem, pág. 72. Es dificil prestar credibilidad al alegato, al menos en base a este triunvirato: la enemistad entre los Manrique de Lara y los Velasco, Duques de Nájera y Condestables respectivamente, era tradicional (Cooper ap. doc. 252). No he podido identificar al Obispo. El padre de Antonio Manrique de Lara, Duque de Nájera, era primo de la primera mujer del Marqués de los Vélez, de su madrastra y de su yerno. El hijo del Duque se casó posteriormente con la hija del Marqués (Cooper ap. doc. 44). Sin embargo se destacaba por no comprometerse nunca y Acuña pecaba probablemente de exceso de optimismo acerca de su cooperación, sobre todo habiendo sido cogido en los dominios del Duque. El interés del Condestable radicaba probablemente en Ia esperanza de arrebatar por fín el arcedianato de Valpuesta de las manos de Acuria. Otro visitante del prelado en Simancas fue el arcediano de Treviño, un agente del deán de Burgos (Guilarte, pág. 172).
}

Hispatio, LVI/2, núm. 193 (1996) 467-495 
Emperador en Roma, Juan Manuel, antiguo aliado de Alvar Pérez Osorio, solicitó obstinadamente la absolución papal para la pena de muerte ${ }^{45}$. Tal vez se había vinculado en su mente el fenómeno comunero con los estragos sufridos en este tiempo por sus castillos palentinos (Montealegre, Belmonte) ${ }^{46}$.

Sin embargo, Nassau pudo ser portador de noticias esperanzadoras provenientes del reducto episcopal de Fermoselle. Localizada junto a la frontera portuguesa, esta población zamorana domina una desmoronada extensión occidental de la meseta castellana, vigilando la desembocadura del Tormes en la hoz del Duero, cuyo meandro la dota de un foso natural por tres lados. A pesar de su lejanía, Fermoselle es bastante grande, con un total de alrededor de 2.000 habitantes en la baja Edad Media ${ }^{47}$. Aunque no queda prácticamente nada ni del castillo ni de las murallas, sería difícil asediar el sitio, localizado como está en una plataforma ataludada de roca viva, con curiosas casas de granito concentradas como rebaños pétreos. La proximidad a Portugal facilitaría, además, la entrada de avituallamientos.

El 10 de junio de 1521, la Corona había nombrado alcaide de Fermoselle al capitán Bernardino de Carvajal ${ }^{48}$. Sin embargo, debido probablemente a la indulgencia de Diego de Muros, la población estaba todavía en manos de partidarios de Acuña un año más tarde. El 12 de junio de 1522 se mandó al teniente Carlos Osorio, pariente del Obispo con toda probabilidad, que lo entregara al Conde de Alba de Liste (en nombre del Obispo de Oviedo). Osorio se resistio pretextando la conocida enemistad del Conde con Antonio Acuña. Se respetó este principio y el día 14 se expidió otra orden análoga, esta vez a nombre de Pedro de Porras, portero de cámara ${ }^{49}$. Esta medida parece haberse cruzado con el cumplimiento por Osorio, el día 16, de la orden del 12 de junio, con una demora de 20 días a la espera de soluciones alternativas ${ }^{50}$. Es posible que Osorio no hubiera recibido aún la segunda orden, pero debio sospechar lo que iba a ocurrir dándose cuenta a la vez que Porras, por muy neutral que fuera, no íba a ser el aliado secreto que hacía falta. Cabe suponer que había detectado la inminente

45 Ibidem, pág. 175.

46 CoOPER, il. 284, etc.

47 La existencia de una judería en Fermoselle está bien documentada. Sin embargo no parece que hubiera más de una parroquia y en el núcleo medieval de la iglesia cabrian un máximo de cien personas. En ausencia de otros indicios (no se ha localizado la sinagoga) parece que debió haber una gran mayoría de habitantes judíos, posiblemente alrededor del $90 \%$. Muchos se marcharon seguramente con la expulsión de 1492 dada la proximidad de Portugal. ¿Quiénes vivían entonces en Fermoselle en 1520?. Las cifras de población de la tercera década del siglo XVI indican poco cambio.

Estas circunstancias pueden explicar la actuación de Acuîa en la expedición de los Gelves ya que estas islas tunecinas albergaban una de las comunidades hebreas más grandes del mundo islámico, predominando los judios de origen hispánico. Si se hubiese despoblado Fermoselle es posible que Acuña propusiera restablecer la comunidad a base de conversos de los Gelves.

48 Archivo Municipal de Zamora 2 fol. 71 ,I.

49 La orden, expedida en Palencia, invalida la del 12 de junio, citada en el texto (AGS RGS junio de 1522, sin foliar).

50 COOPER, pág. 144.

Hispania, LVI2, núm. 193 (1996) 467-495 
aparición de alguno y no quería frustrar una posible ventaja entregándola al impecable Porras. Pronto aparecio un aliado, un tal Lucas de Tauste, un insignificante ex-racionero de la catedral de Guadix ${ }^{5 t}$.

He demostrado la probabilidad de que Tauste fuera enviado a Fermoselle por el Marqués de los Vélez para intentar mantener el castillo en nombre del Obispo Acuña ${ }^{52}$. El apellido aragonés Tauste existía en esa época en Castilla no sólo en Yeste y Baeza (ambas infiltradas por el Marqués) sino en el mismo Vélez Blanco. Es probable que el racionero guadijeño conociera personalmente a Acuña, que había ejercido además cierta influencia en el obispado de Almería, diócesis del marquesado de los Vélez ${ }^{53}$. Una de las tareas de Acuña como oficial de la Corona había sido la de comisario de la armada en la segunda expedición a los Gelves para la que fue nombrado el 27 de enero de 1519 54. Esto le llevó a Cartagena desde donde se carteó con el Marqués y donde al mantener una postura neutral en una contienda regional, le hizo un favor que supondría el posterior apoyo del Marqués durante la época comunera ${ }^{55}$. No puede ser pura coincidencia que el Marqués fuera íntimo amigo del anciano Enrique de Nassau, casado con la primogénita de Rodrigo Mendoza, Marqués del Cenete ${ }^{56}$. Tampoco la visita de Nassau a Antonio Acuña encarcelado en Simancas fue inocente.

En el otoño de $1521{ }^{57}$ Diego Vázquez de Cepeda había vuelto a Zamora. Cabe suponer que evitaba comprometerse con el contumaz Obispo. El 23

51 El 21 de junio se mandó a Carlos Osorio que entregara el castillo a Lucas de Tauste (ibidem).

52 Ibidem. La clave es el hecho de que durante el tiempo en que estuvo vacante la sede el mando real de la diócesis de Guadix lo ejerció el provisor Gaspar Dávalos, posteriormente Cardenal Dávalos. Los episcopologios no precisan la fecha de la muerte del Obispo Garcia Quijada y se limitan a situar en 1522 el comienzo de la vacante. De hecho se produjo probablemente con anterioridad. Cabe suponer que Dávalos era incondicional del Marqués porque éste había pagado sus estudios en la Sorbona. Cuando actuaba de juez comisario en la formación del obispado de Orihuela en 1518 se inactividad sirvió muy bien a los fines del Marqués. También llegó a ser Obispo de Guadix de 1524 a 1527.

53 El eslabón entre Acuña y Tauste era el vicario de aquél en el arcedianato de Toro, el bachiJler Antón Fernández, también canónigo de Guadix (noticia de 1513, AGS Consejo Real 57-15). Estaba ya instalado en la vicaría desde hacía años cuando entró Acuña en el apiscopado (ibidem, RGS diciembre de 1499 fol. 46). Francisco de Sosa, subdiácono de Zamora, fue consagrado Obispo de Almería en 1515. Habitualmente permaneció en Toro donde murió en 1520.

54 GullarTe, pág. 59.

55 COOPER, ap. doc. 274. Es probable que Acuña estuviera pensando ya en alguna forma de subversión, pues a partir de 1519 retuvo la pensión del Cardenal de Vich pagadera con las rentas del obispado de Zamora (real mandamiento dado en Burgos el 12 de diciembre de 1523 a Gonzalo García, canónigo de Oviedo, para que restableciera la pensión, AGS RGS diciembre de 1523 sin foliar). Como Vich residía en Roma, este dinero le habría venido muy bien a Acuña para viajar a la Ciudad Eterna en ese tiempo.

36 COOPER, ap. doc. 228.

57 El 21 de noviembre de 1521 firmó en Zamora un contrato con el cantero francés Ardoin de Avineo para construir una capilla en el monasterio de san Francisco. MarTl Y Monsó, J., Pleitos de Artistas, Boletín de la Sociedad Castellana de Excursiones III, 1907-8, en entregas, pág. 19.

Hispania, LVI/2, num. 193 (1996) 467-495 
de marzo de 1522 el Conde de Alba de Liste, de nuevo al mando del Regimiento, se valio de la enfermedad mortal de un regidor para presionar a la Corona para que suspendiera los trámites para proceder a la rápida elección de un sucesor sumiso, Alonso Vázquez de Cepeda, pariente, con toda probabilidad del deán ${ }^{38}$. Este mismo año, cuatro días después de ser destinado Tauste, es decir el 25 de junio, se produjo en Zamora un hecho de máxima importancia, especialmente por lo que implicaba para los toledanos y para el desgraciado Obispo de Zamora. Se mostraron las reliquias de san Ildefonso nada menos que al propio Emperador ${ }^{59}$. El séquito fue mínimo destacándose sólo el Conde de Alba de Liste y el Obispo de Ciudad Rodrigo, Juan Tavera, posteriormente Arzobispo de Toledo. No asistió el Deán. La siguiente aparición de Diego Vázquez de Cepeda en un cabildo, que hay documentada, es del 12 de septiembre de 1522, después de un vacío de tres años, habiendo desparecido entretanto Pedro Pérez. La ocasión fue un Capítulo para la elección de Tauste a una media-ración ${ }^{60}$. No se trató de una simple gratificación rutinaria, síno del estipendio (aunque no la canonjía, que siguió desierta) del difunto Fernando Hontañón de Medinilla, secretario del Obispo. Curiosamente Tauste se autodenomina "clérigo de la diócesis de Jaén". No existen referencias documentales a este respecto ni evidencia de los derechos de Tauste al mismo ${ }^{61}$. Parece una falsedad: la aparente aceptación de Tauste por el deán sólo tiene sentido si el cabildo viera en el guadijeño la forma de impedir la incautación por parte de la Corona de los recursos del obispado, máxime cuando éstos, en algu-

58 El inválido era Antonio de Guadalajara, tío de Alonso Vázquez de Cepeda. No fue un simple peón en el juego, pues había sido procurador de Zamora en las Cortes de Burgos de 1512. Alonso Vázquez fba a reservar el regimiento para su hijo. El arreglo indica, según las normas de la época, que éste era menor de edad. El Conde declaró descaradamente: yo tengo el negocio por mío (AGS Cámara de Castilla, Mernoriales 155-23).

59 FERnÁndez PrIETo, op. cit., pág. 38. La evidente urgencia de esta inspección indica que por una vez no se trataba de una simple ceremonia, sino una constatación de que las reliquias estaban todavía en su sitio.

60 Archivo de la catedral de Zamora 190. Diecisiete canónigos votaron unánimemente (uno por poderes). La decimooctava canonjía era la del difunto Hontañón de Medinilla. Parece que hubo un ausente no registrado. No hacía falta que Gonzalo Monte ejerciera su prerrogativa de votar dos veces. El ausente que envió su voto, pretextando en carta de 4 de septiembre que estaría demasiado enfermo para asistir al capítulo, era el tesorero Antonio Ocampo (véase nota 33).

61 Aunque exista una autorización de 14 de junio para que transfiriera su ración de la catedral de Guadix a un sobrino, no se sabe si hizo uso de ella. Un documento expedido en Burgos el 30 de septiembre de 1523 (véase nota 72) es el primero de varios que le señalan como canónigo de Guadix. Aunque da la impresión de que Tauste se autoproclamó, la única referencia fiable de su canonjía es muy posterior (véase nota 101). En 1514 Tauste había sido nombrado canónigo de Canarias y arcediano de Fuerteventura y es posible que hubiera retenido también estas dignidades.

Las condiciones establecidas para la ración zamorana no prohiben la ocupación de beneficios en otros sitios, sino simplemente que Tauste cohabitara con una mujer en el plazo de dos meses (antes o después) de la elección. Tal vez esta es la razón por la que no se lo ofreció la canonjia, presumiblemente más rigurosa, de Fernando Hontanón. 
nos casos, constituían los propios medios de vida de los canónigos. Si hubiesen sospechado que Tauste pensaba facilitar el regreso del Obispo, al menos el deán y el subdeán no lo hubieran aprobado.

A pesar del apoyo del cabildo Tauste no parece haber logrado controlar Fermoselle. El traslado de Acuña a Simancas se produjo al mismo tiempo que la elección de Tauste y la proximidad del Obispo a su diócesis hizo prioritario que Tauste controlara otros puntos claves, especialmente mientras se mantenía firme el régimen pro-Acuña en Fermoselle: aunque no hay más referencias de Carlos Osorio como alcaide, está claro que el castillo seguía en manos de los partidarios de Antonio Acuña tan tardíamente como octubre de $1523^{62}$. La situación dejó libre a Tauste para apropiarse del curato de san Juan de Fuentesaúco ${ }^{63}$. Esta iglesia, estratégicamente crucial, templo de un señorío privativo del obispado, había sido fortificada por Acuña en 1507 durante su primera ocupación de la Mitra ${ }^{64}$. Efectivamente, la ocupación de Tauste es casi idéntica: el 6 de diciembre de 1522, la Corona envió a las autoridades de Fuentesaúco el siguiente mandamiento:

don Carlos etc. a vos el alcalde mayor e alcaldes ordinarios... de la villa de la Fuente de Sauco... salud e gracia: sepades que Francisco Cerezo cantor e capellan del ovispo de Vurgos nos hizo rrelacion... que antes de la portada del puerto de Tarrag(on)a nuestro muy santo padre Adriano le dyo provysion motu propio del veneficio de la yglesia de esa dicha villa que es de las diogas de Camora el qual diz que baco por muerte de Albaro Gomes (de Jaén)prior de Salamanca cuya provysyon ansy por rrazon de la dicha vacante como por ser el dicho prior protonotario

62 Bajo un sucesor anónimo de Diego Romero, vecino de Zamora. Los vecinos de Cibanal encausaron a Acuña por el proceder del alcaide de Fermoselle (probablemente Romero) y el 22 de noviembre de 1522 la Corona en Valladolid habia mandado al corregidor de Zamora que investigara (AGS RGS noviembre de 1522 sin foliar). En Burgos el 5 de octubre de 1523 Romero fue emplazado por haber incitado al entonces teniente de Fermoselle a exigir 12.300 mvds. a los vecinos de Cibanal, a pesar de la franquicia que habían conseguido (ibidem, octubre de 1523 sin foliar). Todo esto a pesar de la orden real expedida en Valladolid el 5 de junio de 1523 que ordenaba a quien conrolase Fermoselle que lo entregara al consejero real Francisco Mendoza (véase nota 95) (ibidem, junio de 1523 sin foliar). Cibanal está situado justamente el este de Fermoselle, en el camino de Fuentesaúco.

63 En Valladolid el 23 de octubre de 1522 la Corona mandó a Pedro Vallejo, cantor de Briviesca juez apostólico que permitiera, si cumplía las normas protocolarias, la apelación de Tauste, cura de san Juan de Fuentesaúco, contra el entredicho eclesiástico impuesto a instancia de Francisco Cerezo (ibidem, octubre de 1522 sin foliar). Vallejo era agente del deán de Burgos.

64 Véase nota 11. Fuentesaúco fue crucial no sólo en el contexto diocesano, sino con respecto a las posibilidades de que Acuña intentara fugarse de Simancas a Portugal: el único plan viable par el prelado habría sido dar la vuelta por el norte de Tordesillas a Villalar, evitando la Mota del Marqués, y cruzar el Duero al oeste de Toro. Aparte del río, el riesgo de esta zona era el bloque de encomiendas de la Orden de san Juan en el valle del Guareña, en donde introducirse hubiera significado la traición. Se habría dirigido entonces hacia Venialbo. Aunque pertenecía a la Mitra no tenía suficiente casco urbano para proporcionarle más que un refugio momentáneo. Pero no dista mucho de Fuentesaúco, y alcanzada ya esta población, tendría escondite y apoyo. De no haberle encontrado entonces la Corona, dificilmente le habria interceptado después.

Hispanja, LVI/2, núrm. 193 (1996) 467-495 
apostolico e familliar del papa Alixandre hera rreservada a su santidad e queno envargante lo suso dicho e teniendo el el dicho titulo legitymo diz que con syniestra rrelacion fue proveydo del dicho titulo legitymo diz que... Llucas de Tauste $e$ otras personas encastillaron la dicha yglesia e la tienen encastillada... por que vos mandamos ... que... La dicha yglesia.. la desencastilleys... e castygad a los llegos que en ello alardes culpantes... dada en la billa de Valladolid a seys dias del mes de diziembre año... de myll e quinientos e veynte e dos años el licenciado Santiago el licenciado Polanco el licenciado de Qualla el dotor Beltran el dotor Guebara Acuña el dotor Tello secretario Anton Gallo 65

El control de Fuentesaúco habria sido de primera importancia para Tauste, no sólo por las fortificaciones, de las que nada queda hoy en día, sino por el beneficio eclesiástico del fallecido Alvaro Gómez, probablemente un eslabón esencial con la jefatura comunera de Salamanca. Tal vez el beneficio de san Juan fue la recompensa de Gomez por retirarse de la disputa sobre las tercias de Casasola. Sin embargo, a primera vista no parecería necesaria la implicacion de Tauste ya que Francisco Cerezo era pariente cercano de Francisco Ortega, deán de Almería y aliado del Marqués de los Vélez ${ }^{6}$. Presumiblemente, como sacerdote burgalés, Cerezo intervino por la presión del deán del Burgos, Pedro Suárez de Velasco. Finalmente la conexión almeriense resultó más fuerte y retiró su reclamación (que de todas formas carecía de validez).

La reanudación de la lucha por el control de Fuentesaúco no impidió que Tauste procediera a la ocupación de otros lugares estratégicos de la diócesis y a hacerse con todos los ingresos diocesanos que pudo ${ }^{67}$. En algún momento, logro que Muros lo nombrara receptor de las rentas del obispado durante los

65 AGS RGS diciembre de 1522 sin foliar.

66 COOPER pág. 320. Como Acữa en Zamora, el converso Juan Ortega, Obispo de Almería, había retenido sus emolumentos burgaleses, e instalado a clérigos de Burgos en las vacantes de su dí́cesis. Uno de los testigos de su testamento (murió el 1 de abril de 1515) era Andrés Ortega Cerezo, subcantor y racionero de Burgos. GARCla CAMPRA, E., Juan de Ortega, primer obispo de Almería, Almería entre Culturas, siglos XIII-XVI, vol. I, Almería, 1990, págs. 335-363. El cómplice de Acuña en el atentado de 1526 fue su capellán en Simancas, Bartolomé Ortega, cura de Wamba (Zamora), de parentesco desconocido.

67 A pesar de la orden dada a Tauste por Diego de Muros, la Corona nombró al contino Cristóbal Saldaña receptor de las rentas del obispado. Este alegó que Tauste habia recaudado rentas e impuestos desde 1512, traficado en granos y leña, despoblado de árboles el monte de Almendre (Toro) y acumulado un fondo de 18.000 ducados. Además había manipulado las pujas en una subasta de 1522, causando un déficit de 400.000 mvds. El camarero de Acuña, el padre Riaño, había escondido alhajas con un valor de 12.000 ducados. En Valladolid el 16 de enero de 1523 la Corona mandó a las autoridades de Zamora y Toro que indicaran a Saldaña las medidas necesarias (AGS RGS enero de 1523 sin foliar). Más: en 1507 Gonzalo Monte se había llevado la plata de la iglesia de Fermoselle, emplazamiento a consecuencia de una denuncia del mayoirdomo de santa María de Fermoselle, expedido en Valladolid el 24 de abril de 1523 (ibidem, abril de 1523 sin foliar). Si son verdad estas aseveraciones, Monte, Tauste y Riaño deberian estar en posesión de casi todo el rescate de Acuña.

Hispania, LVI/2, núm. 193 (1996) 467-495 
años 1521-2. Aunque esto probablemente era necesario para poder financiar cualquier intento de soltar a Acuna de Simancas, llevó a Tauste a un enfrentamiento directo con la Corona ${ }^{68}$. No tardó en tropezar con problemas, pero al mismo tiempo mostro sus grandes recursos y su tenacidad y es posible que gracias a su resistencia se prolongase la escasamente considerada administración del Obispo de Oviedo ${ }^{69}$. En Fuentesaúco se defendía bien y en Villamor desvió una disputa desde un alcalde de corte hacia Pedro de Mazariegos, protonotario apostólico, uno de los canónigos zamoranos que le habían dado su voto en septiembre de $1522{ }^{70}$. Esto revela más bien una peligrosa falta de unanimidad en el cabildo que la existencia de un aliado clandestino ${ }^{71}$. Al mismo tiempo explica porqué más de un año después de su elección, Tauste seguía controlando no solamente Villamor sino también los ingresos del episcopado ${ }^{72}$.

El logro tal vez más notable de Tauste fue el establecimiento de cierto grado de control sobre el resto del territorio entre Fuentesaúco y Fermoselle (una distancia de $85 \mathrm{kms}$.). Incautó los ingresos del beneficio de Fresno de Sáyago (a unos $34 \mathrm{kms}$. al este de Fermoselle). Los reclamó Diego de Chaves,

68 Es la documentación sobre este asunto la que denomina habitualmente a Tauste canónigo sin especificar de donde.

69 En Valladolid el 16 de enero de 1523 la Corona mandó a Tauste que desistiera de sus intentos de expulsar a Saldaña de la administración de Villamor, y le informó que se le habia retirado la autorización para recaudar las rentas del obispado. El mismo día se le dírigió también un emplazamiento, expedido a instancias de Saldaña, ya veedor y escribano de cámara (ibidem, enero de 1523 sin foliar). Villamor de los Escuderos está situado al oeste de Fuentesaúco, camino de Fermoselle.

70 En Valladolid el 23 de marzo de 1523 la Corona mandó a Pedro Vallejo que publicara su reclamación contra Lucas de Tauste sobre el beneficio de Fuentesaúco pretendido por Francisco Cerezo, pues el testimonio de Tauste enviado al Consejo Real indicó que Vallejo debía probarlo o anular la censura eclesiástica (ibidem, marzo de 1523 sin foliar).

Mazariegos era pariente, aunque no se trataba del regidor commero del mismo nombre. Como en otras ciudades los integrantes del cabildo catedral tenían su origen en los linajes del patriciado urbano que dominaban también el Regimiento.

"Por ejemplo sobre el priorato de Zamora, vacante a la muerte de Juan de Mena, y en litigio desde el 3 de julio de 1518, fecha de una expectativa papal esgrimida por Juan Rodriguez de Tapia delante del cabildo el 2 de octubre de 1522 (Archivo de la Catedral de Zamora 144, caja I). Como Tapia venía de Plasencia, sede vacante, fue nombrado probablemente por el Arzobispo de Santiago. El otro pretendiente, partidario de Acuña, el bachiller Germán de Ugarte, fue fiscal de la Inquisición de Aragón. Las votaciones encabezadas por el canónigo Diego de Valencia y el racionero Pedro López respectivamente, son semejantes a las del 4 de octubre de 1520 (véase nota 33).

72 A pesar de la orden de 16 de enero, Tauste seguía recaudando los atrasos de las rentas de la diócesis, declarándose responsable únicamente ante el fiscal de la Corona. Le puso a prueba el canónigo Rodrigo de Villagómez, quien pretendió que se le debia un estipendio de 3.000 mvds. durante 12 años por el curato de Villamor. Mazariegos, como juez apostólico, rechazó la apelación de Tauste contra esta demanda. Sin embargo en Burgos el 30 de septiembre de I523 la Corona, influida probablemente por la actitud de Tauste hacia el erario, mandó que se aceptara su apelación siempre que no hubiera ningún problema burocrático (AGS RGS septiembre de 1523 sin foliar). Es este documento el que se refiere por primera vez a Tauste como canónigo de Guadix.

Hispania, LVI/2, núm. 193 (1996) 467-495 
otro canonigo que le había dado su voto en septiembre de 1522. En Valladolid el 10 de junio de 1523 se mandó al contino Cristóbal Saldaña que pusiera las rentas en cuestión en manos de vecinos de confianza y se suspendio al juez eclesiástico responsable del caso ${ }^{73}$. Tauste y Chaves se las arreglaron entre $\mathbf{s} 1$ permutando las propiedades de Tauste en Fresno por un beneficio de Chaves en Peñausende, situado a mitad de camino entre Fermoselle y Fuentesaúco. Entretanto los representantes de Saldaña en Fresno se encontraron con que no podían obtener el dinero pues Tauste habia arrendado las fuentes que lo generaban ${ }^{74}$.

El control de Tauste sobre Peñausende fue esencial. Aparte del hecho de que después de Fermoselle era la fortaleza más fuerte de la diócesis al sur de la ciudad de Zamora (debido a su curiosa forma geológica más que a la existencia de ninguna fortificación notable) fue encomienda de la Orden de Santiago. Esto significó que Tauste gozaba de cierto nivel de seguridad sobre todo siendo el comendador Pedro Pacheco, primo de Antonio Acuna ${ }^{75}$. De la misma edad que el Obispo, era a la vez regidor de Ciudad Rodrigo y vecino de Murcia. Por esta razón estaba en una situación inmejorable para establecer contactos entre Tauste y el Marqués de los Vélez.

En el momento de la llegada de Tauste al obispado se produjo un cambio fundamental en la imagen pública de otro protagonista del encarcelamiento de Acuña, el Conde de Alba de Liste. Los relatos tradicionales han hablado de una profunda hostilidad entre Acuña y él, que llegaría a su culmen en la rebelión de las Comunidades. Sin embargo, el Conde no era enemigo de los rebeldes, especialmente al principio, ni tampoco consta el antagonismo con Acuña hasta la negativa de Carlos Osorio de entregar Fermoselle ${ }^{76}$. Dos acontecimientos refuerzan esta impresión de armonía: la elección del secretario del Conde como procurador en agosto de 1519 por parte del deán y el cabildo y la rivalidad en torno a la vacante de san Ciprián de Zamora en $1520{ }^{77}$. El Conde reclamó el derecho de presentación pero el 5 de junio Gonzalo Monte propuso a otro candidato. Si habra un momento ideal para una confrontacion en vísperas de la rebelión, era éste. Sin embargo, el candidato de Monte (y por lo tanto de Acuña) se retiró ${ }^{78}$. Durante el desarrollo de la rebelión tampoco hay indicios de hostilidad entre Conde y Obispo.

El cambio, que hay que relacionar con Tauste, coincidirá con un aumento de los esfuerzos de los rivales del Marqués de los Vélez encabezados por el

73 En Valladolid el 10 de junio de 1523 se ordenó a Saldaña que informara a la Corona sobre todos estos asuntos (ibidem, junio de 1523 sin foliar).

${ }_{74}$ En Valladolid el 7 de julio de 1523 se mandó a los arrendadores que reembolsaran directamente a la Corona (ibidem, julio de 1523 sin foliar).

75 Teniendo en cuenta estas circunstancias es probable que Peñausende le sirviera de base para las actividades aqui detalladas.

76 Véase la fuente de la nota 31.

77 Véase nota 28 . La noticia dada en la nota 29 apoya esta interpretación.

78 Zamora: Archivo del Episcopado, Mitra 248-2. 
pariente del Conde, Fadrique de Toledo, Duque de Alba, para hundir su monopolio político y minero en Murcia. El Duque ya había descubierto sus intenciones a este respecto en 1503, aunque en esa época no podía establecerse una conexión clara con los acontecimientos desarrollados en la lejana diócesis de Zamora ${ }^{79}$. El fallecimiento de García de Toledo, primogénito del Duque, en el fracasado intento de 1510 de tomar los Gelves, impuso a éste la necesidad de asegurar la sucesión del ducado en la persona de su nieto, el futuro "Gran Duque de Alba». Al mismo tiempo tuvo que evitar una nueva amenaza de reparto de sus dominios como hubiera ocurrido si llega a fallar este arreglo, como amenazó con suceder en 1488 en su propia sucesión. Una de sus medidas para asegurarlo fue el enlace del resto de su prole con nobles bien situados y fiables, como el Conde de Alba de Liste, casado con su hija Aldonza Leonor.

De hecho esta unión pudo tener lugar antes de 1510. El Duque había intervenido probablemente para conseguir la capitanía general de Rosellón para el padre del Conde. El propio Conde tuvo que hacer frente a problemas sucesorios pues su padre murió antes que su abuelo, fallecido en 1502. Es lógico que el Duque actuara también en esta situación para asegurar la sucesión del Conde. Este habría devuelto el favor haciendo la vista gorda ante el desheredamiento de su propio hermano menor, Enrique Enriquez, sospechoso de deslealtad a los ojos del Duque. La connivencia llega a su punto culminante con el intento de 1521 de la abuela del Conde (tía del Duque) de destituir a Enrique Enríquez de la alcaidía de Baza denunciandolo como comunero.

La importancia de Baza en esta situación estuvo en su proximidad a los aliados de Enrique Enríquez, en particular el Marqués de los Vélez, y a su propio patrimonio, centrado en El Tahal en la Sierra de Filabres, Orce y Galera (situados todos, como Baza, en la diócesis de Guadix, tierra de Lucas de Tauste). El golpe de Baza gozó de un éxito temporal y completó además la neutralización sistemática de las operaciones del Marqués en Murcia culminada por el nombramiento del criado ducal Diego de Sotomayor como corregidor de Murcia el 14 de junio de $1521{ }^{\circ 0}$. Vélez sufría entretanto reveses constantes en Murcia y se encontraba indefenso en los límites occidentales de sus dominios almerienses, sobre todo después del fallecimiento del suegro de Nassau, Rodrigo de Mendoza, Marqués del Cenete, el 23 de febrero de 1523.

Cenete fue posiblemente de gran ayuda a la causa comunera, tanto o más que su famosa intervención en las Germanías de Valencia. Sin duda ayudó a

79 COOPER, ap. doc. 274 .

80 Owens, J. B., Rebelión, Monarquía y Oligarquía Murciana en la Epoca de Carlos V (Murcia, 1980), pág. 127. Fue sustituído el 10 de diciembre de 1522 por Carlos Guevara, un incondicional del Marqués de los Vélez (AGS RGS diciembre de 1522 sin foliar, dado en Valladolid). Sin embargo el cambio no permitió al Marqués recuperar su ascendiente.

A pesar de los esfuerzos del Duque en su contra, el hermano del Conde de Alba de Liste se hizo cargo de su herencia en 1530 cuando murió su abuela (Cooper, pág. 722). Posteriormente el hijo de Enrique Enriquez se casó con la hija del Marqués de los Vélez.

Hïspania, LVI/2, núm. 193 (1996) 467-495 
mantener la vacante en el episcopado de Guadix, en cuya diócesis está situada la Calahorra (cabeza de su marquesado), una joya arquitectónica señorial ${ }^{\text {B1. }}$ Además uno de los principales comuneros salmantinos, Pedro Maldonado, fue, hasta su ajusticiamiento en 1521, escribano mayor de rentas no solamente de Ciudad Rodrigo, sino también de las Alpujarras, limítrofes con el obispado de Guadix ${ }^{82}$. Es probable que Maldonado pusiera a disposición de la causa comunera sus inmensas riquezas ${ }^{83}$. En el caso de las Alpujarras tuvo que contar con la cooperación de Rodrigo Mendoza, cuyo marquesado estaba situado entre la serranía y la ciudad de Guadix.

Después de morir Cenete la Corona descubrió que durante su vida había mantenido desiertos los beneficios del marquesado ${ }^{84}$. Hay tres motivos posibles: pudo retener los diezmos para sufragar los gastos astronómicos de la construcción de la Calahorra ${ }^{85}$; las vacantes evitarían que la Corona se entremetiera en la administración del marquesado nombrando a clérigos opuestos a él; finalmente la situación protegía a los vasallos moriscos que podrían seguir practicando tranquilamente algunos usos islámicos. Después, en abril y mayo de 1523, fueron cubiertos en poco tiempo casi todos los beneficios ${ }^{86}$.

B1 He descartado cualquier posibilidad de que fuera Cenete quien envió a Tauste a Zamora: sus relaciones con Acữa (bastante anteriores) son hostiles (ibidem, pág. 141, nota 501) y su complicidad con las Germanías no le permitía más compromisos con los rebeldes. Además en el verano de 1522 estaba afectado por una enfermedad mortal. Por otra parte, mientras vivió, resulta inverosímil una intervención de Nassau en Guadix a pesar del papel que jugó en el intento de salvar a Acuña. De todas formas la diplomacia era más propia de Nassau que la subversión. Por su parte Tauste era el típico lugarteniente fiable y duro de Vélez, y sus actividades no sufrirán ninguna interrupción cuando muera Cenete.

82 Según los nombramientos a los dos of icios de Juan Osorio, hijo del difunto Alvar Pérez Osorio, Marqués de Astorga, expedido en Burgos el 16 de septiembre de 1523 (AGS RGS 1523 sin foliar). Los términos en cuestión fueron: Alicún, Jubiles, Majeme, Boloduy, Berja y Dalias (no todos estrictamente alpujarreños) con Quentar, Salinas de la Malaha y Azalian. No se conoce la razón por la que se llevaban conjuntamente las escribanías.

${ }^{83}$ Pérez, págs. 486 y 488.

84 Cabe suponer que obstaculizó la notificación de las vacantes a los provisores de la diócesis. Sin embargo Martín Abad de Otañes, clérigo de la diócesis de Burgos, destinado a Ferreira del Marquesado (Burgos, 16 de septiembre de 1523, AGS RGS septiembre de 1523 sin foliar), se encontró con que ya ocupaba su beneficio Bernaldo de Narváez, nombrado hacia 1510 por el Rey Católico pero proscrito del marquesado por orden de Rodrigo Mendoza, según mandamiento real dado en Burgos el 30 de septiembre de 1523 al deán y cabildo de Guadix para que enviaran al Consejo Real la documentación pertinente (ibidem., septiembre 1523 sin foliar).

85 COOPER ilustraciones 686-690.

B6 En Valladolid el 29 de abril de 1523 la Corona nombró a Juan de Bonifacio, clérigo de Burgos, para una vacante en los tres beneficios de Lanteira. Idem Sancho de Torres, clérigo de Almería, para los beneficios de Aldeire del Marquesado y Alonso López, clérigo de Jaén, al otro. Cristóbal de la Torre idem nombrado para un beneficio (de tres) de Jerez del Marquesado (AGS RGS abril de 1523, sin foliar). Idem Iñigo de Legartegui idem. Idem a Lanteira Sancho Ibarra idem. Valladolid, 15 de mayo de 1523 se nombró para el beneficio de Chercos (Filabres) a Juan Rodríguez de Leciñana, clérigo de Calahorra (ibidem). 
Cabe suponer que todos los nombramientos tuvieron un sesgo político, aunque que se sepa, no predominó ningún interés particular. Otros nombramientos a beneficios en zonas colindantes están relacionados probablemente con esta situacion ${ }^{87}$.

El cambio más importante en la zona después de la muerte del Marqués del Cenete tuvo lugar en el señorío de Vélez de Benaudalla, en el extremo occidental de las Alpujarras. En la Reconquista de Granada había sido cedido a Juan de Ulloa, el de Ias tercias de Casasola, entonces simplemente alcaide de Salobreña ${ }^{88}$. Su lealtad a la Corona durante las Comunidades fue puesta a prueba cuando fueron incendiadas las casas de su mayorazgo en Medina del Campo, durante la conflagración provocada deliberadamente el 21 de agosto de $1520^{89}$. De hecho los comuneros asaltaron su señorío de La Mota del Marqués (al norte de Tordesillas). EL proyecto de reconstrucción del castillo no llego a llevarse a cabo ${ }^{90}$.

La proyectada reconstrucción de La Mota de 1524 formó probablemente parte de un programa de reestructuración de los recursos de Juan de Ulloa para que, desde el punto de vista de la Corona, se le pudiera recompensar su apoyo, y no fuera víctima de represalias de antiguos comuneros. En Valladolid el 23 de julio de 1523 se le autorizo a comprar el mayorazgo del rebelde ajusticiado Ramiro Núñez de Guzmán ${ }^{91}$. Parte del efectivo para llevar a cabo esta gestión procedería de la liquidación de sus propiedades de Medina del Campo cuestión para la cual fue autorizado a principios de mes, y cuya rehabilitación fue impedida por intereses comuneros persistentes en el municipio ${ }^{92}$. En aquel estado ruinoso la propiedad no tendría mucho valor asi que el resto del capital necesario para adquirir el patrimonio de los Guzmán se habría obtenido vendiendo Vélez de Benaudalla y Guajara Baja (hoy día Guajar-Fondón) al Conde de Alba de Liste ${ }^{93}$.

87 Especialmente, desde ltrego, la iglesia de Santiago. Huéscar (señorío del Duque de Alba, también diócesis de Guadix). En Valladolid el 23 de enero de 1523, la Corona informó a las autoridades del arzobispado de Toledo que Pedro Sánchez de Bariga había renunciado a su beneficio en favor đe Cristóbal Cobos, clérigo de Jaén (ibidem, enero de 1523, sin foliar). En Logroño el 9 de octubre de 1523 la Corona mandó al deán y cabildo de Toledo que aceptara otro clérigo más de la diócesis de Calahorra, Juan Garay, para ocupar el beneficio de Juan Fernández Moreno, expulsado por los comuneros en 1521 (ibidem, octubre de 1523, sin foliar). En otra parroquia de Huéscar, Santa María, Sancho Ibarra y Juan Comejo, presbítero de Cartagena, fueron nombrados para beneficios de frutos supercrecientes (en Valladolid el 18 de julio de 1523 (ibidem, julio de 1523 sin foliar). No consta, sin embargo, ninguna renuncia de Ibarra a su recien adquirido beneficio de Lanteira.

88 Cooper, pág. 734.

89 En la batalla de Villalar buscó, según parece, a Juan Padilla y le acuchilló. En ausencia de un motivo especial para la venganza personal cabe suponer que Ulloa culpó a los comuneros de la destrucción de su familia al seducir a un hermano y a un primo, cabecillas del movimiento en Toro y Zamora.

90 COOPER, ap. doc. 450 .

91 AGS RGS julio de 1523, sin foliar.

92 En Valladolid, a 4 de julio de 1523 , Ulloa fue autorizado a venderlas (ibidem).

93 Idem (ibidem).

Hìspania, LVV/2, núrt. 193 (1996) 467-495 
De estas dos gestiones no ha aparecido más documentación que las autorizaciones. Sin embargo parece que se llevaron a cabo, aunque la posesión de Vélez de Benaudalla por el Conde habría sido efímera en vista de su adquisición por Alvaro de Bazán en el plazo de 18 meses ${ }^{94}$. La ocupación coincidió precisamente con el control de Lucas de Tauste de los fondos necesarios y de una vía de escape para el encarcelado Antonio Acuña. El breve régimen del Conde de Alba como vecino de Enrique de Nassau (recientemente sucedido en el marquesado del Cenete) puede haber servido como aviso al Marqués de los Vélez. En cualquier caso no se corrió ningún riesgo: el 30 de marzo de 1523 Adriano VI había nombrado a Francisco Mendoza Córdoba administrador de la díccesis de Zamora ${ }^{95}$. Aunque éste tardo algún tiempo en arreglar el caos del interludio de Diego de Muros, Tauste seguía sin moverse.

La oportunidad de Acuña de escapar por la vía abierta por Tauste se desvaneció en septiembre de 1523. Después del fallecimiento de Adriano VI el día 14 la Corona empezó a temer repercusiones en la diócesis de Zamora, sin duda porque el racionero de Guadix todavía andaba en pleitos. Juan Manuel recibió ordenes para solicitar al siguiente Papa (Clemente VII, elegido el 19 de noviembre) la prórroga del mandato de Mendoza, y se mando al deán y al cabildo de Zamora que continuaran cumpliendo sus instrucciones hasta que se tramitara su nuevo encargo:

porque podria ser que entretanto vos otros o alguno de vos disiendo que por fin del dicho nuestro muy santo padre espiro el dicho breue (el mandato de Mendoza) quisyeredes o tentasedes hazer alguna novedad en ello ${ }^{96}$.

Sin embargo, Tauste ya no podía contar con la connivencia de Muros ${ }^{97}$. Tenía que tratar además con un deán y un cabildo en desorden y probablemente se encontró maniatado, primero por la vacilación de Vélez y luego por la paralización de Nassau al pensar que la incomparable Calahorra podía estar en peligro ${ }^{98}$.

94 COOPER, pág. 734. Entretanto, en Burgos el 3 de octubre de 1523, la Corona había mandado a Juan de Ulloa, nuevo seffor de Barrillos en el valle de Toreno, antiguo sefiorío de Ramiro Núfiez de Guzmán, que garantizara la seguridad de los vecinos (ibidem, octubre de 1523, sin foliar).

9s GuILARTE, pág. 179 , nota 136.

96 Pamplona a 19 de noviembre de 1523 (AGS RGS noviembre de 1523, sin foliar).

97 En un documento del 10 de junio de 1523 (véase nota 73) se seffala a Tauste como canónigo de Oviedo. Como Pedro González Manso, Muros era corresponsal de Pedro Mártir, carteándose éste, al mismo tiempo, con su antiguo alumno el Marqués de los Vélez (es al Marqués a quien mantiene Mártir al tanto de Ja situación en Zamora en mayo de 1520, véase nota 29). Sin embargo es poco probable que Mártir se prestara a una conspiración por dos razones: su rechazo hacia Acữa y el hecho de que no parece haber sdio el depositario de ninguna información confidencial o tendenciosa. Además sus cartas contienen pocas sorpresas: su valor en el contexto de la carrera de Acuña es que demuestran qué grado de intimidad existía entre los principales protagonistas.

98 En 1524 el Duque de Alba llevó a cabo un ataque el marquesado de Cenete provocando la indignación del Marqués de los Vélez (Cooper, ap. doc. 228). El ultraje coincidió probablemente con el traslado de Manso (véase nota 98) de Guadix a Tuy (26 de octubre de 1524) y el abandono de Vélez de Benaudalla por el Conde de Alba de Liste.

Hispania, LVI2, núm. 193 (1996) 467-495 
El 28 de noviembre de 1523 el omnipresente deán de Granada, Pedro González Manso, fue nombrado como cabía esperar Obispo de Guadix, hecho que habría facilitado la reincorporación de Tauste a su propia diócesis ${ }^{99}$. Sin embargo Tauste optó por quedarse en Fuentesaúco a pesar de las desventajas que tenía para él, siguiendo en posesión del beneficio en febrero de 1525. Tan aferrado estaba que la burocracia parecía impotente para expulsarle. Para conseguirlo se recurrio a un oficial que parece haber sido un protegido del Duque de Alba ${ }^{100}$. Cabe suponer que tuvo éxito por fin, aunque esto no impidió que Tauste volviera posteriormente a su carrera guadijeña sin perjuicio ${ }^{101}$. Mendoza fue el siguiente Obispo de Zamora (3 de abril de $1527^{\text {102 }}$ ). Ironicamente su padre, el Conde de Cabra, había acaudillado la expedición de 1519 a los Gelves, cuyos veteranos, al no ser pagados se alistaron en las filas comuneras ${ }^{103}$.

99 La Corona, como patrón, autorizó al deán y cabildo de Guadix a aceptar el nombramiento (en Pamplona, AGS RGS noviembre de 1523, sin foliar). El astuto Manso colocó inmediatamente a un allegado, Pedro García de Tavanera, clérigo de Segovia, en Hueneja, uno de los beneficios que quedaban vacantes del marquesado del Cenete (ibidem). Manso había sido anteriormente juez apostólico de clérigos exceptuados. Por estas atribucjones devolvió los bienes confiscados de Alonso de Pliego, el comunero deán de Avila (real mandamiento dado en Burgos el 16 de diciembre de 1523 al oficial Arias Méndez para que se conformara con el juicio de Manso, ibidem, diciembre de 1523, sin foliar). Desgraciadamente para Acuña no era Manso quien actuó en su caso.

100 Fernando del Barco, Obispo de Salonia, prior de san Andrés extramuros de Salamanca, bachiller en santa Teología. No puede ser otro que el licenciado del Barco, figura en listas anónimas de la época de licenciados salmantinos aptos para los altos oficios públicos, posiblemente oidor del Consejo Real. Su ficha dice: es buen letrado e tiene buena conciencia e es hombre sin necesidad $e$ eclesiástico. Fue del consejo del cardenal fray Francisco Jimenez e del cardenal de Croy. Es natural del Barco de Avila. BELTRAN De Heredia, V., Propuestas de Personal Académico para cargos de Gobierno (Acta Salmanticensa 1970, págs. 497-530) núm. 555 y 557 (años 1523-5, repetidos). Ahora El Barco de Avila era señorío del Duque de Alba como sabrían perfectamente los destinatarios de este memorial.

El Obispo/prior fue nombrado para arbitrar la disputa sobre Fuentesaúco entre Tauste y el sucesor de Cerezo, Martín de Espinosa, veterano en escaramuzas clericales en Salamanca (Cooper, ap. doc. 324). El 31 de enero de 1525 del Barco aconsejó a la Corona que condenara a Tauste por intruso (AGS Consejo Real 89-8); Es este veredicto, en especial, el que elimina cualquier posibilidad de que, en lugar del papel perfilado aquí, Tauste pudiera ser la vanguardia zamorana de la comisión de amnistía del Arzobispo de Granada convocada en enero de 1523 para proteger los beneficios de los clérigos exceptuados. Aparte de la disparidad de fechas, Tauste nunca alega este cargo en su defensa. El candidato natural habría sido, en cualquier caso, Pedro González Manso.

Gaspar de Montoya (véase nota 33) también es considerado apto para un cargo de gobierno; asimismo Manso (no había sido alumno de Salamanca, que se sepa) e incluso Espinosa a pesar de que Pedro Mártir le considera corrupto (red. López de Toro, carta 636).

101 En Monzón el 11 de julio de 1542 la Corona aprobó el nombramiento de Tauste al arciprestazgo de Guadix a cambio de la canonjía que tenía, que se transferitía a Luis de Amézcua, menor de edad a pesar de que no era bachiller (AGS Cámara de Castilla, libro 107 de Cédulas, fol. 158r.).

102 Tuvo que suceder a Muros en la diócesis de Oviedo hasta el ajusticiamiento de Acuña. En la práctica, sin embargo, tenía el poder de hecho en el obispado de Zamora desde la instalación de Clemente VIL.

103 GuILARTE, pág. 112.

Hispania, LV/2, núm. 193 (1996) 467-495 
Diego Vázquez de Cepeda murí a principios de noviembre de $1525^{104}$. Su fallecimiento hubiera podido acabar con la aceptación de la presencia de Tauste. Por otra parte es posible que precipitara la última extravagancia del Obispo. La caída de Acuña ha pasado a la mitologia de la Historia. Tras aguantar más de tres años de prisión después de las hazañas iniciales de Tauste asesinó a su carcelero Fernando Noguerol, el 25 de febrero de 1526, e intentó huir inutilmente. Dado el apoyo clandestino que tuvo en 1523 es diffcil imaginar que no fuera animado a huir, estando en los sesenta, con la vista deteriorada, aislado del mundo exterior durante cerca de cuatro anos y medio y acabado desde cualquier punto de vista. Acufia se hubiera encontrado totalmente desvalido tan pronto como salvara el foso de Simancas. El sucesor de Noguerol íba a ser el mismo Enrique de Nassau. ¿Se trató de un nombramiento hábilmente maquinado?. Si fue así llegó tarde. Acuña fue ajusticiado el 26 de marzo de 1526 y Nassau tomó el cargo el 15 de julio de $1527{ }^{105}$.

En su testamento Acuña pidió ser enterrado en san Pedro de Zamora pero la cofradía de san Ildefonso fue intransigente y yace en la parroquia de Simancas. Bajo tortura reveló la identidad de sus supuestos colaboradores en su funesta escapada final ${ }^{106}$. No se mencionó a nadie del ámbito de Tauste. Es posible, que a pesar de su angustia, el Obispo supiera disimular. Sin embargo es más probable que el Marqués de los Vélez pensara que ya era tarde y no merecía la pena volver atrás o que no estaba en posición de ofrecer un apoyo efectivo cuando él mismo había caído: el Duque de Alba había logrado prácticamente exiliarle y el nuevo Obispo de Almería se empeñaba en mermar sus rentas ${ }^{107}$.

Desde luego estos hechos son susceptibles de una interpretacion totalmente diferente si, por ejemplo, seguimos las pistas señaladas por J.I.

104 Firmó el codicilo final de su testamento el día 5. Los documentos testamentarios descubren más sobre sus contactos y posibles afiliaciones que ninguna otra fuente: no figura como beneficiario ni albacea nadie del cabildo catedral, cosa insólita para una persona de su categoría, carente al mismo tiempo de familiares y amigos. Casi todos los legados, en general de cantidades irrisorias, son para instituciones religiosas. La única excepción, además con mucho la donación más grande, fue la dotación de su ambiciosa capilla funeraria, no en la catedral, sino en el monasterio de san Francisco. A pesar de estaextravagancia y del origen patricio del deán, con parientes en la corte real, Diego Vázquez no murió rico. 0 era un administrador inepto o, como indican estos datos, la aventura de Acuña le costó caro, en bienes y aliados. Archivo de Ia Real Chancillería, Valladolid: Rodriguez Taboada, pleitos civiles fenecidos C.1157-I (esta es la signatura moderna de la fuente consultada en 1907 por Martí y Monsó).

105 Técnicamente, fue el consejero real Hernando de Vega, fallecido en 1523, a quien sustituyó Nassau pues Noguerol era el teniente de aquel. Así, el sucesor efectivo de Vega fue probablemente su primo, Lope de Vega. No se sabe la fecha de su incorporación como teniente.

106 Entre ellos el Obispo de Sigüenza (Guilarte, pág. 236), lo que no parece muy probable (véase nota 26). La Corona no hizo uso de estos conocimientos.

107 COOPER, págs. 319 y 321 . Ninguno de estos adversarios logró destruir el monopolio del Marqués en el comercio del alumbre, y no es de extrañar que el nieto del Duque de Alba se asegurara en 1567 el puesto de gobernador de los Países Bajos, desde donde podría socavar las operaciones comerciales del Marqués desde el otro cabo de la red de distribución.

Hispania, LVI/2, num. 193 (1996) 467.495 
Gutiérrez Nieto ${ }^{108}$. Desgraciadamente el enfoque clerical de las Comunidades no disipa el misterio si atendemos a Lucas de Tauste y Diego Vázquez de Cepeda, ambos cruciales en la evolución de los acontecimientos en Zamora. Aunque se descubrió pronto la ficción del puesto oficial a que aspiraba el racionero de Guadix, consiguió mantener secretas sus verdaderas credenciales. No obstante su importancia viene indicada, al menos, por la cantidad de documentación que gener6 y la magnitud de las operaciones necesarias para apartarle. En el caso del deán tampoco ha podido ser identificado definitivamente por falta de datos genealógicos. De su trayectoria entre el otoño de 1518 y el de 1521 solo se tiene noticia de su ausencia.

Tampoco los derechos a los diezmos de la zona de Toro ofrecen más que un aparente condicionamiento económico para el activismo clerical de la rebelión de Zamora para el apoyo de las diócesis vecinas de Salamanca y Oviedo: al extenderse la rebelión la recaudación de los impuestos se convirtió pronto en una usurpación indiscriminada. Es posible, sin embargo, que el problema de los diezmos se generalizara y se sabe que durante el periodo que Acuña encabezó la rebelión de su propia diócesis pasó la mayor del tiempo en Toro, donde se centraba la polémica. Además el asunto habría sido fundamental para Alvaro Gómez de Jaén a quien fue encomendado el reducto clave de Fuentesaúco. Al ser considerado como exceptuado únicamente logró evitar el castigo al morir en el exilio. Los mismos nobles en quienes buscaba apoyo Acufa solian participar en la cobranza de los diezmos como las tercias de Casasola. Su vacilación, por lo tanto, además de típica, es comprensible. La aparente disposición de Vélez, Pedro Girón y otros a apoyar las ambiciones de Acuña, animó a éste a excederse y más tarde, en el momento de la verdad le fallaron.

108 GUTHérRez NIETo, J. 1., Las Comunidades como Movimiento Antiseñorial, Barcelona, 1973, págs. 339-374.

Hispania, LVI2, nưm. 193 (1996) 467-495 

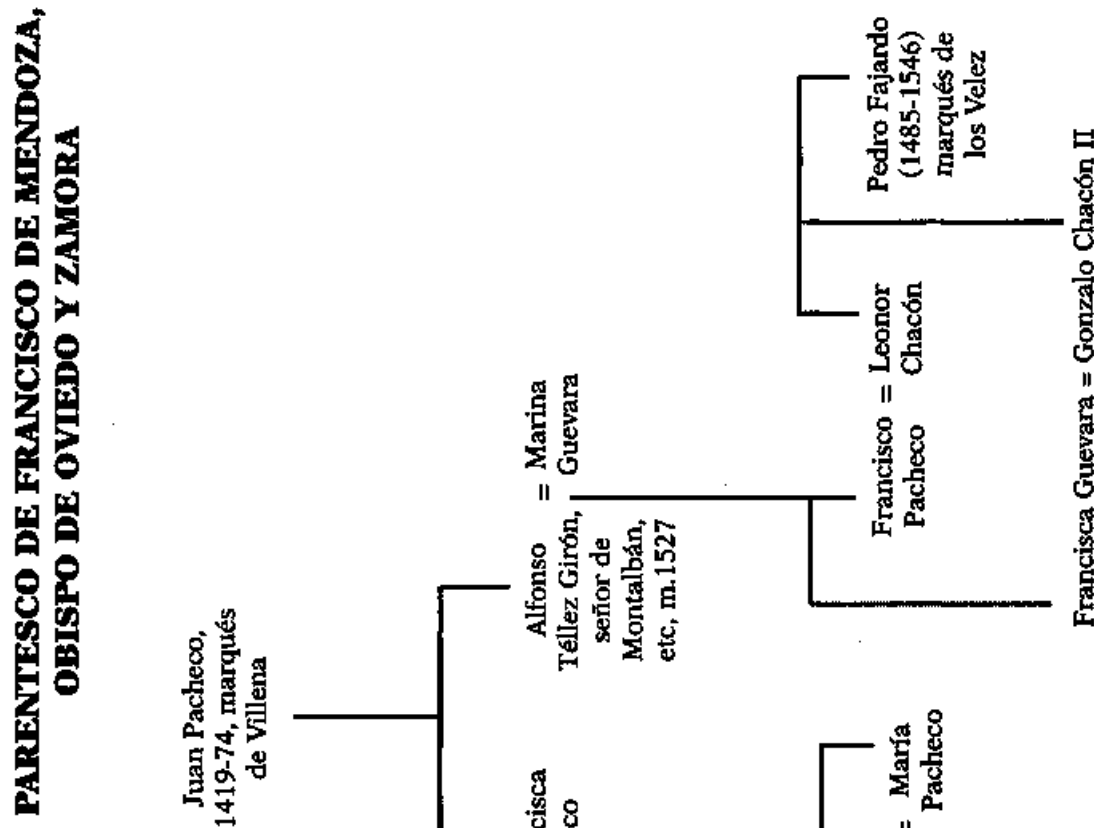

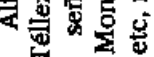

$$
\text { (1) }
$$

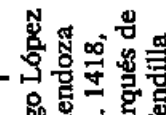

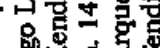

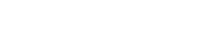

政

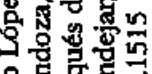

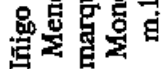

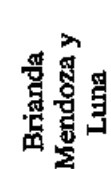

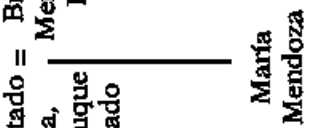

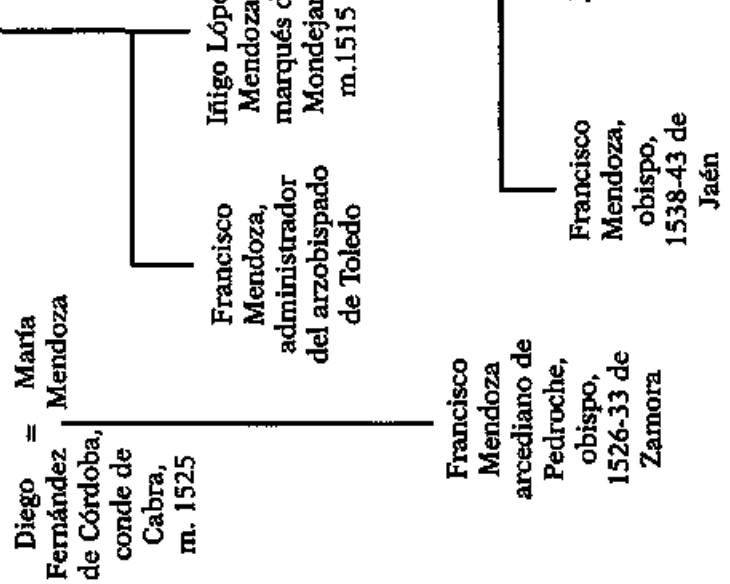

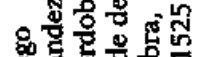

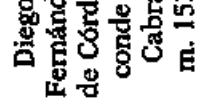

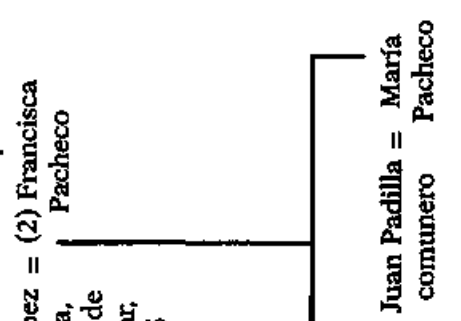

密

II

善

㝵

要焉

Hispania, LVI/2, mim. 193 (1996) 467-495 


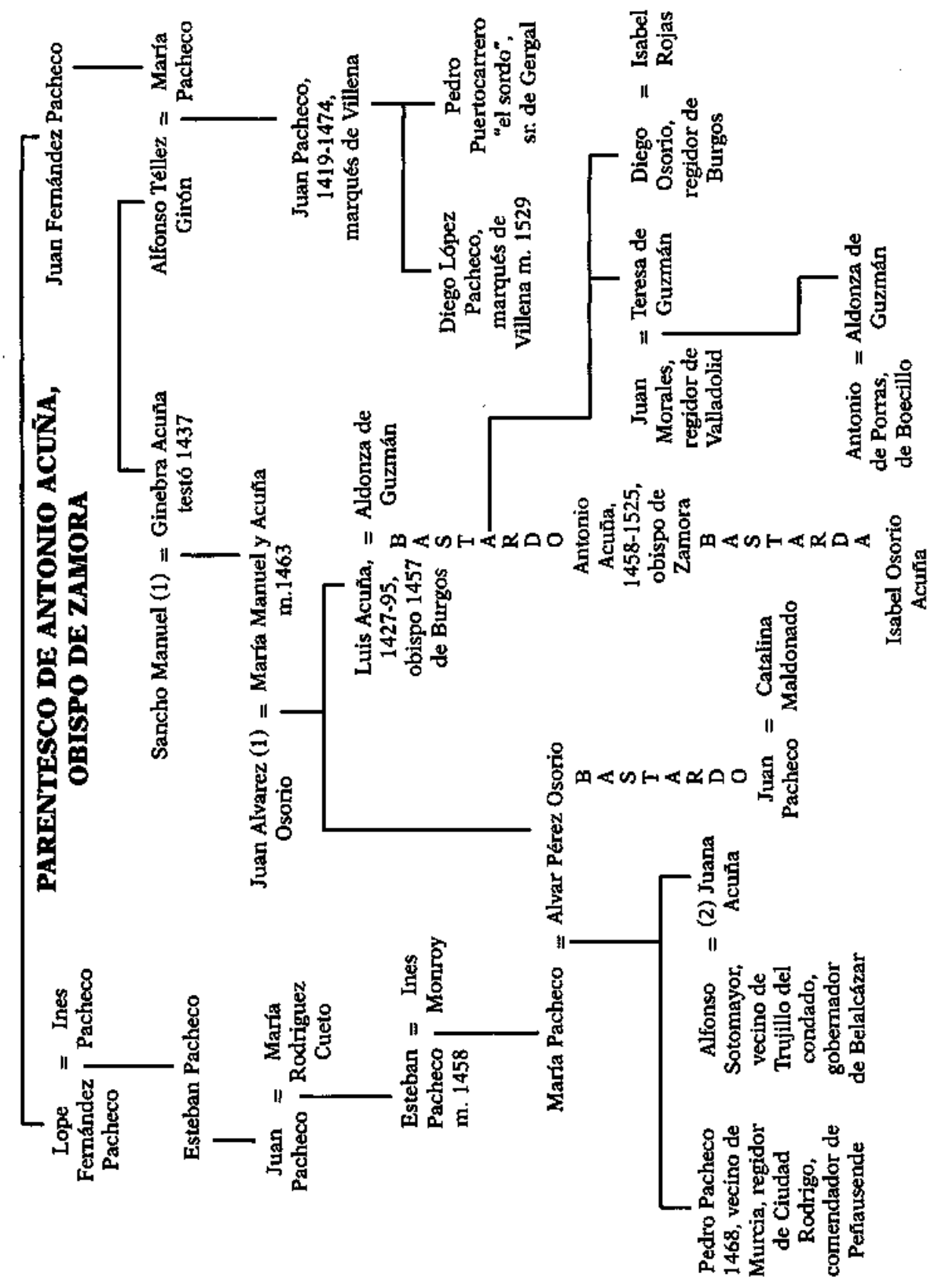

Hispenia, LVI/2, nứm. 193 (1996) 467-495 


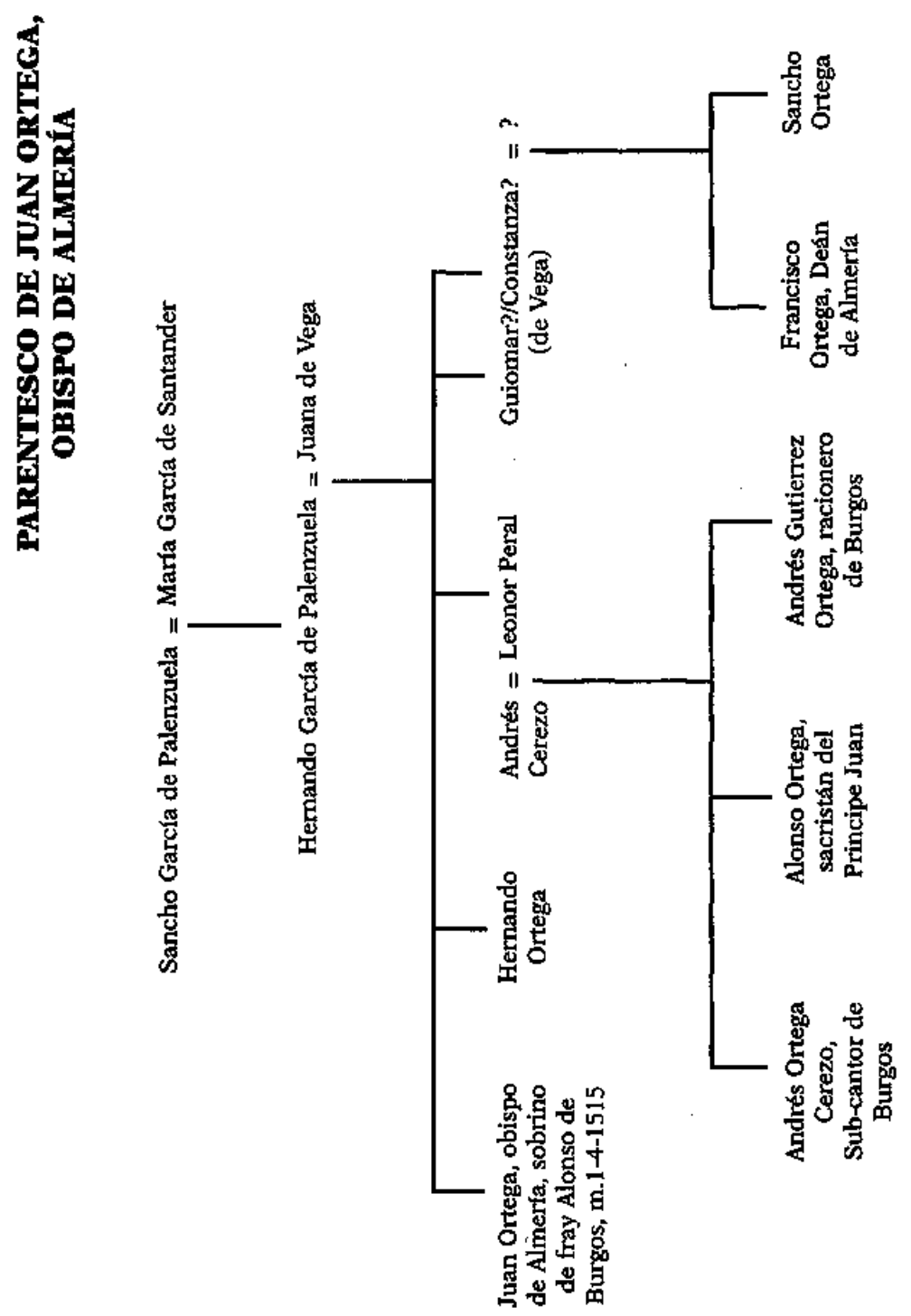

Hispania, LVI/2, núm. 193 (1996) 467-495 